\title{
Messinian event in the black sea: Evidence of a Messinian erosional surface
}

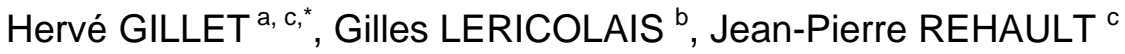

\author{
a. Université Bordeaux 1; CNRS; UMR 5805-EPOC, Talence, F-33405 France \\ b. IFREMER, Centre de Brest, DRO/GM, Technopôle Brest-Iroise, BP 70, 29280 Plouzané, \\ France. \\ c. UMR 6538 - Domaines Océaniques, UBO-CNRS, IUEM, Place Nicolas Copernic, 29280 \\ Plouzané, France. \\ Corresponding author address: \\ Hervé GILLET, UMR 5805 - EPOC, Université Bordeaux 1, Bat B18, Avenue des Facultés, \\ 33405 TALENCE, France, h.gillet@epoc.u-bordeaux1.fr Tel. 00.33.(0)5.40.00.36.04, Fax \\ 00.33.(0)5 56840848
}

\begin{abstract}
:
In 1975, sediment cores from leg DSDP 42b (sites 380A and 381) revealed a thin sediment layer in the Black Sea basin which points to a shallow water environment at the Miocene-Pliocene boundary. With these facts and in the wake of hypothesis of the Messinian Salinity Crisis (MSC), it was proposed that the Black Sea, like the Mediterranean Sea, suffered a desiccation period at the end of the Messinian (Hsü, K.J. and Giovanoli, F., 1979. Messinian event in the Black Sea. Palaeogeography, Palaeoclimatology, Palaeoecology, 29: 75-93). Whereas the main topics of the MSC in the Mediterranean Sea is now widely accepted, the lack of evidence for a Messinian erosional surface in the Black Sea left the debate about the Messinian desiccation of this basin open until today. The analysis of high resolution multi-channel seismic data acquired during the BlaSON surveys brings important new elements for this scientific debate: (1) Down the slope offshore the Bosporus, we show a clear erosional surface correlated to the top of the Upper Miocene shallow water environment unit of site DSDP 381. The overlying Lower Zanclean unit inevitably dates this erosional surface of the Messinian event. (2) A wide intra-Pontian erosional surface (IPU) is evidenced on the Romanian shelf. The IPU is characterized by a sharp decrease in the incision rate from outer (deep canyons) to inner shelf (superficial incisions network). According to the most recent Paratethyan and Mediterranean stratigraphic scale correlations, the IPU erosional surface is considered as the analogue to the Messinian erosional surface described down the slope offshore the Bosporus. In addition to recently discovered inland erosional signature, the wide regional erosional surface we underline on the Western Black Sea margins validates the Black Sea Messinian desiccation hypothesis. We also demonstrate that evaporative draw-down of the Black Sea implied the installation in the basin of a negative hydrologic budget during the Messinian. The lack of a major Messinian Danube canyon on the Romanian shelf supports the hypothesis of a Messinian Danube trapped in the Dacic basin. However, the presence of a Messinian superficial incision network connecting the location of the modern Danube delta to deeply incised Messinian canyons on the outer shelf (IPU) makes the hypothesis of a Danube reaching the partially desiccated Black Sea still possible.
\end{abstract}

Keywords: Black Sea; Messinian erosional surface; seismic stratigraphy; Messinian salinity crisis 


\section{Introduction}

In the early 70's, seismic reflection surveys followed by DSDP drilling data revealed an unexpected thick layer of Messinian evaporites within the sediment pile of the deep Mediterranean basins (Ryan and Hsü, 1973) which led to the famous hypothesis of the Messinian Salinity Crisis (Hsü et al., 1973).

In the Black Sea, some years later, the cored boreholes of the DSDP Leg 42B recovered an unusual lithogical unit at the Miocene-Pliocene boundary at the foot of the slope offshore the Bosporus (Ross and Neprochnov, 1978). This unit, which includes coarse clastic pebbly breccia and stromatolitic dolomite, is considered as deposited in a very shallow water environment (Stoffers and Müller, 1979) suggesting that the sea-level of the Black Sea was very shallow at that time. In the wake of the previous Mediterranean discovery, Hsü and Giovanoli (1979) have interpreted these data as evidence of a drop in level of the Black Sea of up to $1600 \mathrm{~m}$ below the global sea-level in response to the Messinian Salinity Crisis already described in the Mediterranean. Such hypothesis was recently supported by the identification of a Messinian Danube canyon filled by a Zanclean (Lower Pliocene) Gilbert Delta at the outlet of the Iron Gates (western Dacic Basin)(Clauzon et al., 2005).

However, the hypothesis of a Messinian sea-level drop in the Black Sea suffers a major handicap. Whereas the Messinian Salinity Crisis hypothesis is supported in the Mediterranean Sea by the combined identification of two main erosional and sedimentary signatures (Clauzon, 1973; Hsü et al, 1973), the weak point of such a hypothesis in the Black Sea lies in the absence of such an erosional signature on the basin margins.

We present here a high-resolution (HR) seismic stratigraphy study based on multichanel HR seismic data collected during the BlaSON 1 and 2 IFREMER surveys. In order to verify the Black Sea Messinian event hypothesis, we concentrated our research on the identification of major erosional surfaces in the Black Sea. The field investigations of BlaSON surveys was mainly concentrated on the Romanian shelf, where seismic data were correlated with abundant industrial drilling data, and on the Turkish slope offshore the Bosporus, where the two DSDP sites that prompted the Hsü hypothesis (sites 380A and 381) are located.

\section{Paleogeographic setting}

The Black Sea is a land-locked basin, located between Europe and Asia Minor. It is generally considered as a result of a back-arc extension associated with Mesozoic northward subduction of the Tethyan Ocean beneath the Eurasian Continent (Finetti et al., 1988; Letouzey et al., 1977; Okay et al., 1994; Zonenshain and Le Pichon, 1986). At the end of the Eocene times, the paleogeographic reorganization stemmed from the closure of the Tethys and the associated collision of continental blocs resulted in the individualization of two new sedimentary realms on both sides of the alpine orogenics belts: the Mediterranean Sea to the south, and the Paratethys to the north.

The wide intracontinental Paratethyan Sea extended through Central Europe; from the western alpine foredeeps towards the Aral Sea in Asia (Steininger and Papp, 1979). Its present relics are the French Rhone and Swiss Molasse basins (Western Paratethys), the Pannonian basin (Central Paratethys), the Dacian, the Euxinic (i.e Black Sea) (Fig. 1) and the AraloCaspian basins (Eastern Paratethys).

The Upper Eocene to Middle Miocene palaeoenvironmental and palaeogeographical evolution of the Paratethys was characterized by a long term trend of decreasing marine influence and a correlative reduction in size of the sedimentation domains both resulting from the alpine orogenic activity (Meulenkamp and Sissingh, 2003; Rögl, 1999). After the Middle 
Miocene times, Paratethyan conditions evolved into drastically restricted marine environments. The palaeogeographical reshaping rose to a paroxysm: the overall uplift around Parathethys led to the progressive isolation, dislocation and, during Pliocene, to the final filling of most of the Western Paratethyan basins (Meulenkamp and Sissingh, 2003). This Neogene evolution was characterized by several successive closure episodes of the Paratethys marine connections towards the Mediterranean Sea and Indian Ocean (Meulenkamp and Sissingh, 2003; Rögl, 1999).

On one hand, severance of these connections resulted in the development of largely endemic faunas and floras which led to the establishment of specific Neogene stratigraphic scales for the Paratethyan sub-basins (Chumakov, 2000; Papaianopol and Marinescu, 1995; Papp et al., 1974; Rögl, 1998).

On the other hand, the episodic closures of the open seaways led to potential eustatic responses within the isolated basins. Depending on the hydraulic budget of the basin, its base level would evolve toward two main tendencies during isolation phases. Either the hydraulic budget is positive and the level rises rapidly, or the hydraulic budget is negative and the level falls drastically. Because the basins have relatively small superficies, these eustatic responses could reach large amplitudes in a very short time.

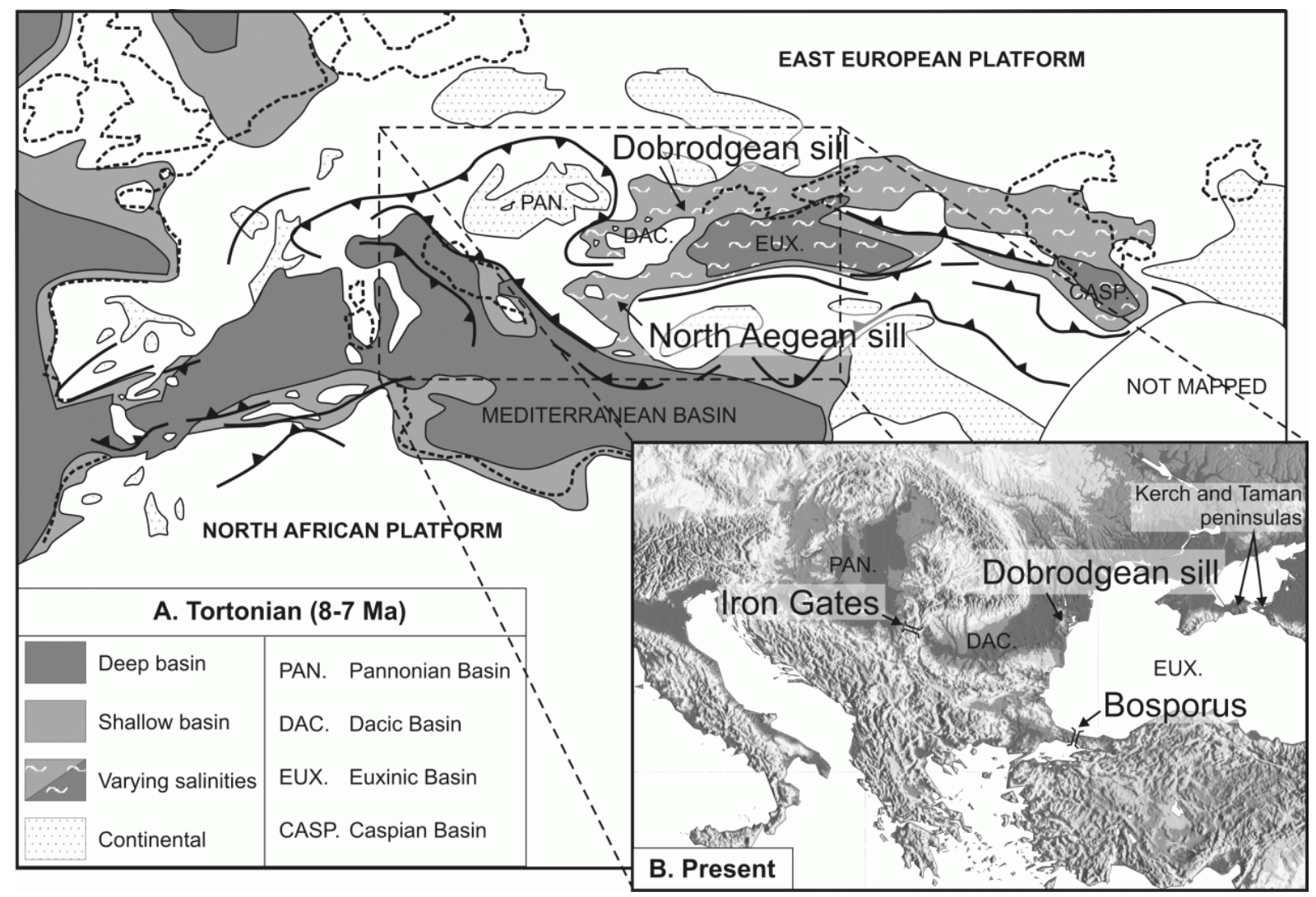

Fig. 1. Geographic setting in Central and Eastern Paratethys. A. Late Tortonian (8-7 MA), after Meulenkamp and Sissingh (2003). B. Present time. 
In the Late Miocene times, just before the Messinian Salinity Crisis in the Mediterranean Sea (Hsü et al., 1973), the Eastern Paratethys, including Black Sea and Dacic basin, was connected to the Mediterranean realm by a shallow sill north of the Aegean Sea (Meulenkamp and Sissingh, 2003; Rögl, 1999)(Fig. 1). Presence of such a connection is supported by the influx of Mediterranean fauna (NN11) recorded in the Dacic basin (Clauzon et al., 2005; Marunteanu, 1992). With regard to this palaeogeographical situation, it has been proposed that the Mediterranean Messinian Salinity Crisis resulted in a complete isolation episode of the Eastern Paratethys. The question of the eustatic response of the Eastern Paratethys to the Mediterranean Messinian Crisis then appeared unavoidable.

\section{Signs of a Messinian event in Eastern Paratethys}

In the Mediterranean domain, the Messinian Salinity Crisis strongly impacted the sedimentation in two ways (Clauzon et al., 2005) : (1) as an immediate consequence, the dramatic fall in sea-level induced the deposition of evaporites in marginal and deep basins (Montadert et al., 1978; Ryan and Hsü, 1973), coupled with the creation of a widespread erosional surface on the shelves (Guennoc et al, 2000; Ryan and Cita, 1978) submitted to subaerial erosion and retrogressive downcutting of deep canyons (Chumakov, 1973; Clauzon, 1973) and the edification of detritic cones at the mouth of the main rivers (Barber, 1981; Lofi, 2005, Savoye and Piper, 1991); (2) the effect of the crisis persisted after its achievement with delayed responses such as the re-filling of the flooded Messinian canyon heads with Gilbert deltas (Gilbert, 1885) during the Lower Pliocene (Clauzon et al., 1995) and the complete rebuilding of the shelf during the Plio-Quaternary (Lofi et al., 2003).

In the Eastern Parathethys, similar signatures have been identified locally suggesting the advent of the Messinian event in this area. However, these signatures concern only a few scattered sites in the Black Sea (sedimentary signature) and the Dacic Basin (erosional signature and delayed effects).

\subsection{In the Black Sea (Euxinic Basin)}

In 1975, sediment cores from the DSDP Leg 42B in the Black Sea revealed a thin layer of stromatolitic dolomite associated to clastic sediments at the Miocene-Pliocene boundary (Ross and Neprochnov, 1978). These deposits were recovered downslope offshore the Bosporus, at sites 380A and 381 drilled at 2107 and $1728 \mathrm{~m}$ water depth respectively. These deposits correspond to the lithological units IVd and 6 described in Fig. 2 and 3. Detailed geophysical, lithological and biostratigraphical analysis of these two drillings is available in the initial report of DSDP Leg 42b (Ross and Neprochnov, 1978).

Unit IVd, encountered at the 864-884 m depth interval in Hole 380A (Fig. 2), consists of an association of pebbly mudstone, stromatolitic dolomite, and cobble-clasts of conglomerates (Fig. 3). The middle part of this unit shows allochtonous tilted dolomitic blocks overlying autochthonous horizontally laminated stromatolitic dolomite beds (Section 3 of core 58, Fig. 3). On both side of these unusual stromatolitic dolomite deposits, the dominant lithology of unit IVd is a coarse clastic, generally referred to as "pebbly breccia", composed of large-sized angular dolomitic clasts embedded in a mudstone matrix. From a lithological point of view, the clasts of the upper part of the unit (section 1 and 2 of core 58, Fig. 3) are identical to the underlying stromatolitic dolomite beds (Section 3 of core 58, Fig. 3), thus suggesting that they were ripped from underlying deposits and transported for a very short distance (Ross and Neprochnov, 1978). 


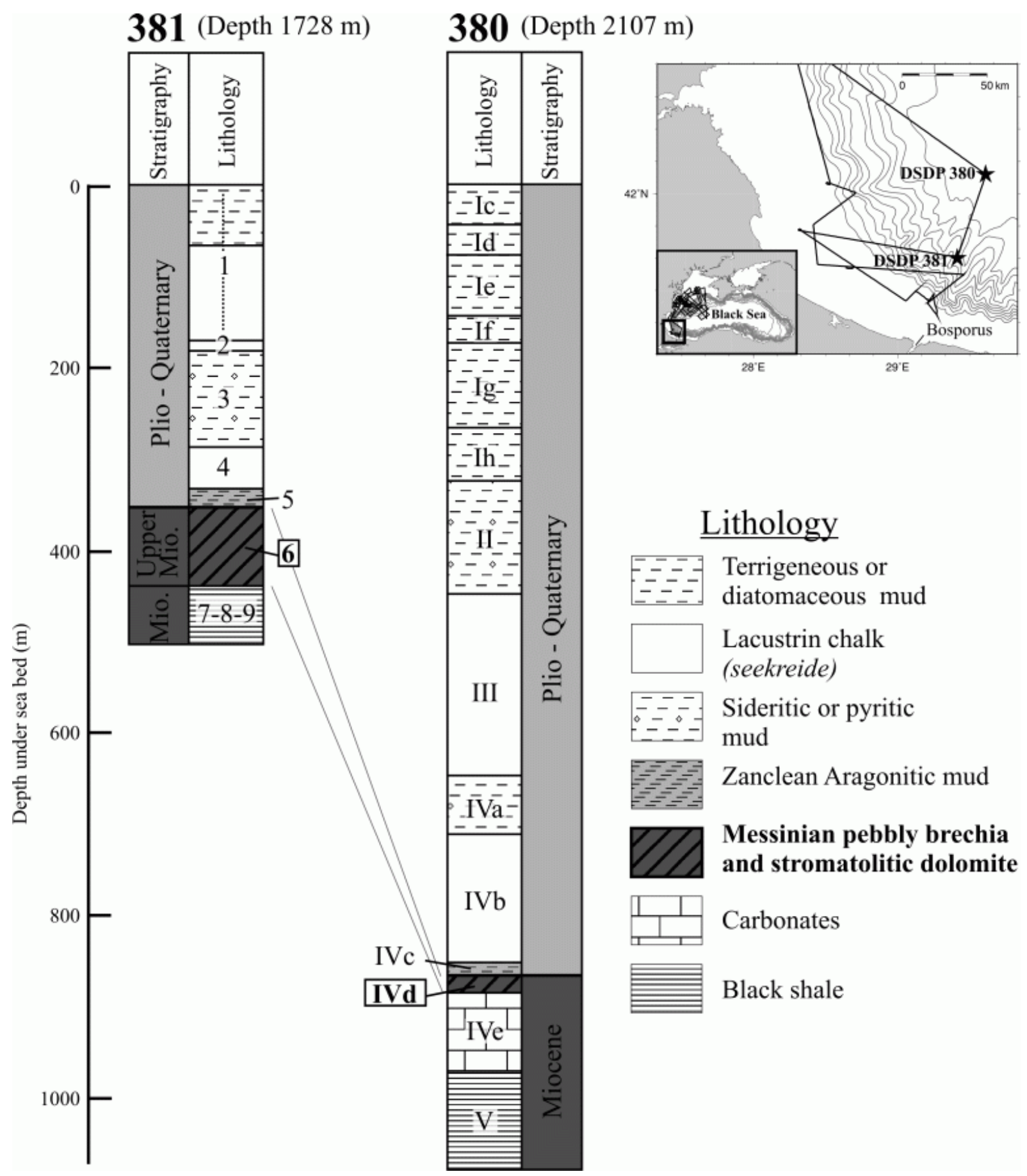

Fig. 2. Stratigraphy and lithology of sites 380A and 381 of leg DSDP 42b, after Hsü (1978). Unit IVd (380A) and Unit 6 (381) are Messinian in age and representative of a shallow water depositional environment. Index map shows the seismic lines covering the study area (Blason Survey). 


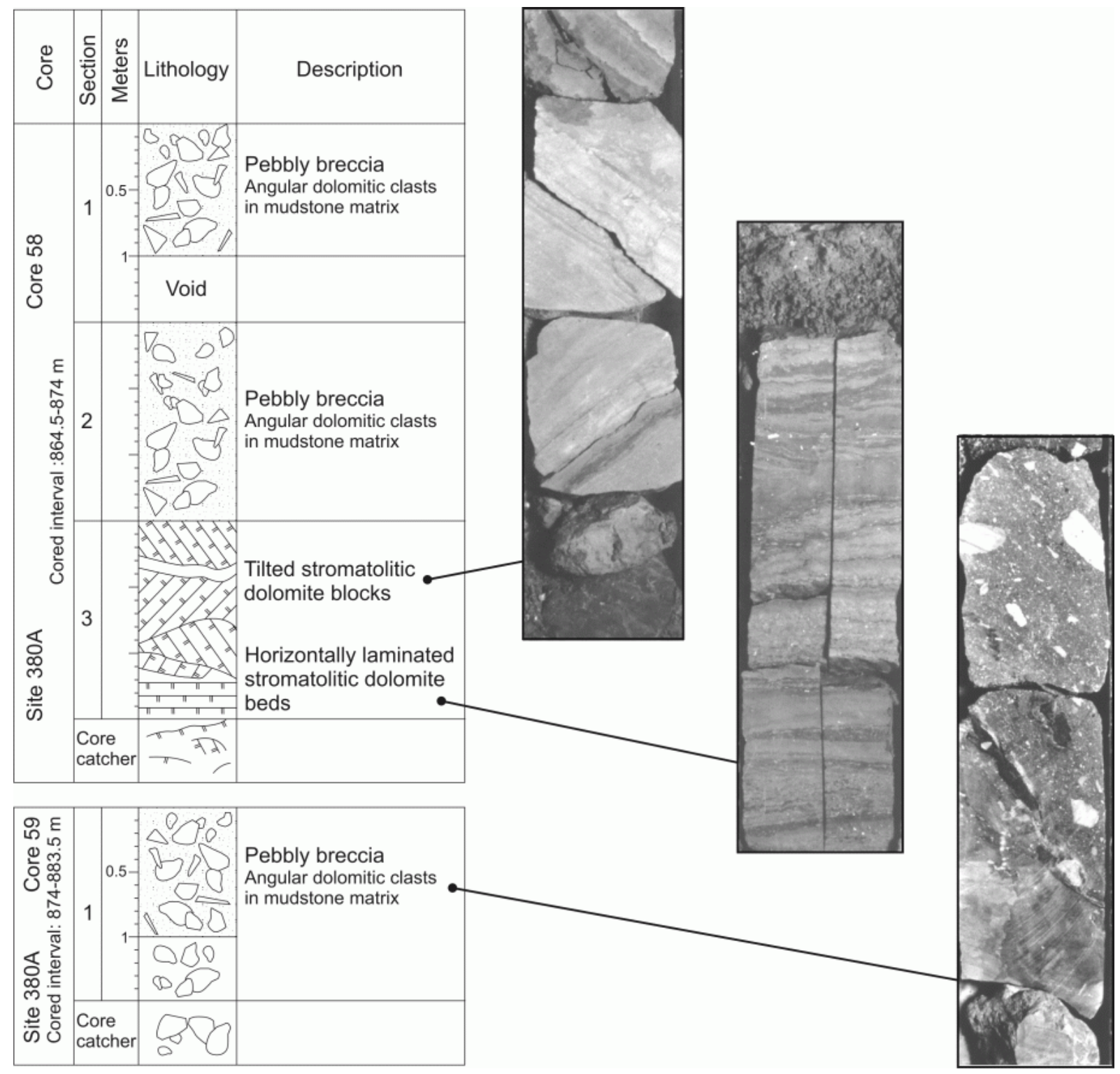

Fig. 3. Detailed lithology of unit IVd (site 380A), after Ross and Neprochnov (1978). 
Unit 6, recovered at the 352-437 m depth interval in Hole 381 (Fig. 2), consists of a mixture of pebbly mudstone, breccia, shellhash, sand, drilling mud and common angular dolomite fragments (Ross and Neprochnov, 1978).

Thin section studies from the dolomitic rocks of both unit IVd (site 380A) and 6 (site 381) revealed a great variety of criteria (e.g. intraclasts, algal mats, crusts, pellets, oolites) indicating a shallow depositional environment with occasional subaerial exposure and evaporitic and meteoric diagenetic alterations (Stoffers and Müller, 1979). Brecciated sediments of site 381 also show abundant evidence of diagenetic modifications (Stoffers and Müller, 1979). Shallow water depositional environment is also evidenced at site 380A by the diatom assemblages suggesting a water depth in the range of a few meters (Schrader, 1978). It has been proposed that the exclusive precipitation of dolomite (first carbonate member of the evaporitic series) has resulted from the predominant alkaline composition of the Black Sea water at this time, thus suggesting that these units deposited in fresh-water environments (Hsü and Giovanoli, 1979; Kojumdgieva, 1983).

It has thus been proposed that Unit 6 from Hole 381 and unit IVd from Hole 380 A are correlative. In addition, at both sites, the sediment recovered below and above these shallow water deposits represent deeper water depositional environments (Hsü and Giovanoli, 1979), thus supporting the hypothesis of a temporary sea-level fall in the Black Sea during the Upper Miocene. Borehole analysis also revealed a change in salinity at the Miocene/pliocene boundary. Indeed, the diatoms sampled in unit 7 at site 381 are thought to indicate a fresh water depositional environment, whereas the aragonitic mud in units 5 and IVc contains diatom assemblage indicating an increased salinity (brackish-marine environment) (Schrader, 1978).

From a chronostratigraphic point of view, biostratigraphic studies conducted on diatoms (Jousé and Mukhina, 1978; Schrader, 1978) and benthic foraminifera and crustaceans (Gheorghian, 1978), as well as palynological studies (Koreneva and Kartashova, 1978; Traverse, 1978), indicate that units IVd and 6 are Late Miocene in age and that the top of these two units marks the Pliocene-Miocene boundary (Hsü and Giovanoli, 1979; Stoffers and Müller, 1979). This dating is supported by a recent high-resolution pollen study at site 380A. According to a global climatostratigraphic approach (Popescu, 2006), the lowermost Zanclean age of the aragonitic mud (Unit IVc) overlying the pebbly breccia is demonstrated. In addition, this study confirms the proximal status of the uppermost laminated dolomites recovered in unit IVd.

Hsü interpreted this detritico-evaporitic sediment layer as the sedimentary signature of a drastic lowering of the water-level within the Black Sea basin at the end of the Messinian (Hsü and Giovanoli, 1979). As for the Mediterranean Messinian Salinity Crisis model, he proposed that the Black Sea water level, due to evaporation, dropped very near to the level of the abyssal plain. In this model, the evaporative draw-down was related to a re-organisation of the drainage patterns in central Europe, involving the capture of the Danube water by the retrogressive erosion affecting the exunded Mediterranean margins. The author also interpreted the overlying aragonitic unit as the signature of a marine transgression corresponding to the Zanclean re-flooding of the Mediterranean which ended the Messinian event in both the Mediterranean and the Black Seas. Such a Zanclean re-flooding of the Black Sea is supported by the influx of Mediterranean nannoplanctons (zone NN12) recorded in the Kertch region (Semenenko and Lyul'eva, 1978). 


\subsection{In the Dacic Basin}

The Dacic basin, which comprises the southern Carpathians foredeep, is today totally filled. It corresponds to the present Southern Romania and is delimited to the north and west by the Carpathians, to the south by the Balkan chain and to the east by the Black Sea. During the Late Miocene, this basin was incorporated into the realm of the Eastern Paratethys as the western appendage of the Euxinian basin (Black Sea) (Meulenkamp and Sissingh, 2003). The connections between these two basins were moderately restricted due to the presence of the Dobrogea horst (Rögl and Steininger, 1983)(Fig. 1).

Recent studies in the Eastern Paratethys led to the following discoveries (Fig. 4):

(1) At the outlet of the Iron Gates, where the Danube flows into the Dacic basin after cutting a passage through the Carpathians (Fig. 4), Clauzon et al.(2005) evidenced the presence of a very large Zanclean Gilbert-type fan delta lying above an erosional surface. This surface is visible on the Gura Văii outcrop (Fig. 4), and is interpreted as a Messinian canyon, incising the Carpathians bedrock (Jurassic limestone). This canyon, attributed to a past Danube tributary, joins the axial incision which is almost parallel to the Danube's modern thalweg (Clauzon et al., 2005). The Zanclean age of the Gilbert delta is confirmed by the presence in the bottomset beds of typical molluscs of the Bosphorian regional substage together with nannofossils representative of the zone NN12 (which span the Mio-Pliocene boundary). Additonally, this assemblage implies a Mediterranean influx in this part of the Dacic Basin and is correlated by the authors to the Zanclean transgression.

(2) Boreholes of the western and southern Carpathian foredeep (Fig. 4) reveal a hiatus between the Late Pontian/Dacian deposits and the underlying series: middle Pontian (Ticleni borehole) (Drivaliari et al., 1997) or older layers such as Sarmatian, Oligocene or Cretaceous (Clauzon et al., 2005). This sedimentary hiatus, supports the Iron Gates discoveries as it may illustrate an erosional gap resulting from the presence in this area of the Messinian-Danube and tributaries (Clauzon et al., 2005). In contrast, outcrops located in the north-east part of the Dacic basin (Fig. 4), exhibit continuous sedimentation from the Late Miocene to the Early Pliocene (Marinescu et al., 1981). Subsurface data are consistent with field observations, as many wells revealed a complete Late Miocene sedimentation in the north-eastern part of the Dacic basin (Clauzon et al., 2005). It has thus been proposed that in the southwestern Dacic Basin the Messinian erosional surface developed along the Danube and its main tributaries courses, whereas the northeastern part of the basin remained as a perched lake having recorded a continuous sedimentation during the Messinian (Clauzon et al., 2005) (Fig. 4).The classical Mediterranean signatures of the Messinian Salinity Crisis (major erosion and Pliocene Gilbert Delta edification in canyon heads) are recovered at the outlet of the Iron Gates, thus asserting that the Dacic Basin was severely affected by the Messinian crisis (Clauzon et al., 2005).

Moreover, the Bosphorian from the north-east part of the Dacic basin recorded two successive Mediterranean influxes (zone NN11 and NN12)(Marunteanu and Papaianopol, 1998; Snel et al., 2006). These influxes imply two successive connections at high sea-level between the Mediterranean Sea and the Dacic basin before and right after the Messinian "desiccation" of the Mediterranean.

The above observations led to a new understanding of the Late Neogene relationships between the Mediterranean Sea and the Dacic basin and provided new elements for the understanding of the modalities of the Messinian crisis in these basins. Clauzon et al. (2005) thus recently reconsidered the chronostratigraphy of the Lago Mare event at the scale of the Mediterranean and Black Seas. Otherwise, these influxes led to a precise intercalibration of 
the Mediterranean standard and the regional Paratethyan chronostratigraphic scales (Snel et al., 2006) (see section 4.4).

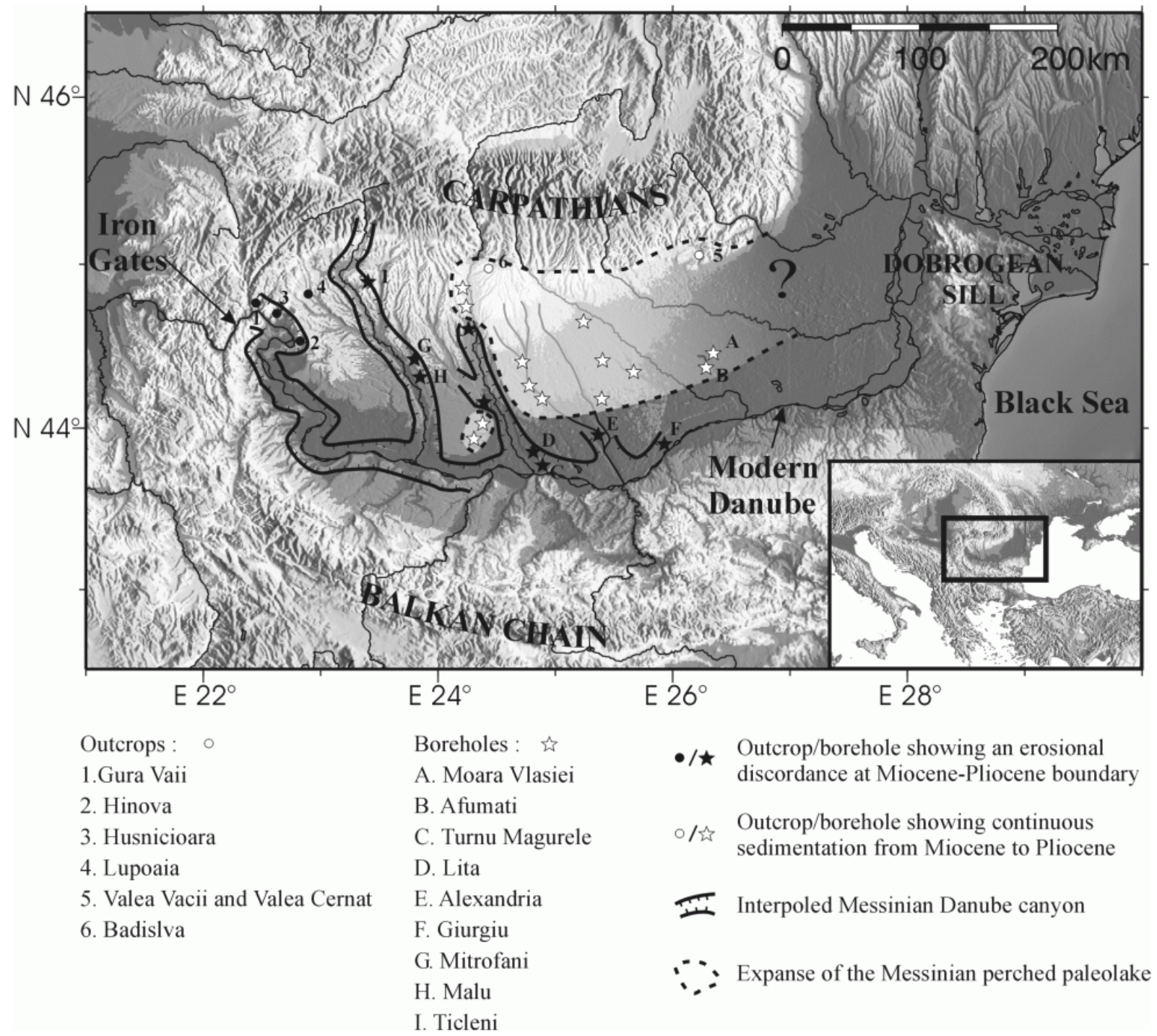

Fig. 4. Modalities of the Messinian event in the Dacic Basin and considered localities, after Clauzon et al. (2005). These authors propose that in the southwestern part of the Dacic Basin the Messinian erosional surface has developed along the Danube and its mains tributaries, whereas the northeastern part remained as a perched lake having recorded a continuous sedimentation. 


\subsection{The missing argument}

The deep desiccated Black Sea model from Hsü and Giovaneli (1979) matches with both the sedimentary arguments and the subsidence constraints of the Euxinic basin and with the Dacic basin recent discoveries. Nevertheless, this hypothesis suffers the lack of a main argument: until now, the major regional erosional surface related to such a Messinian Black Sea desiccation has not been clearly evidenced.

Some clues however suggest that such a surface exists, at least locally. Russian authors pointed out an erosional hiatus at the Pontian-Kimmerian (Messinian-Zanclean) boundary in several sections of the Kerch and Taman peninsulas (northeastern Black Sea, Fig. 1) (Chumakov, 2000; Muratov, 1951; Semenenko, 1987; Zubakov, 2000). Semenenko (1987) and Chumakov (2000) proposed that these erosional signs could be related to a Messinian event in the Black Sea. In addition, on the basin margins, several authors locally spotted on seismic data the presence of an erosional surface at the Mio-Pliocene boundary (Can, 1996; Finetti et al., 1988; Nikolayeva et al., 1980; Robinson et al., 1996). However, such scarce and poorly detailed erosional signs cannot suffice to support the Black Sea desiccation hypothesis. As for the Mediterranean Messinian Salinity Crisis, the definitive validation of the Messinian Black Sea desiccation hypothesis implies the recognition of a wide regional subaereal erosional surface at the scale of the basin.

\section{Data and methods}

\subsection{Seismic data}

The BlaSON 1 and 2 surveys $(1998,2002)$ conducted by the French Research Institute IFREMER in a joint research program between France and Romania, Bulgaria and Turkey, collected more than $9000 \mathrm{~km}$ of High Resolution (HR) multichannel seismic profiles (Fig. 5). These lines were shot across the Western Black Sea, using a mini-GI air-gun seismic source (frequency range centered at $150 \mathrm{~Hz}$ ) and a 24-channel streamer. Such a device displays a resolution of about 10 to $15 \mathrm{~ms}$ combined with a penetration of approximately $1500 \mathrm{~ms}$ (two way time). We processed the data using Landmark-Promax software. The conventional processing flow included the removal of noise traces, CDP gather formation, velocity analysis, normal moveout correction and stack, migration and seabed mute. The analysis of seismic data followed a classical seismic stratigraphic procedure based on the analysis of the reflection ending (erosional truncation, onlap, downlap) and configuration (Mitchum and Vail, 1977). It allowed the identification of the seismic units and their boundaries.

\subsection{Drilling data}

The stratigraphic calibration of seismic data is based on 26 exploratory and scientific boreholes (Fig. 5). They are located on the shelf, except for DSDP 380A and 381, drilled downslope offshore the Bosporus.

On the Romanian shelf, we used data from 22 exploratory wells (Fig. 5) provided by the Romanian Petrom company within a collaboration with the University of Bucharest. Due to confidentiality, these data were restricted to information on the depth (in meters) of the stratigraphic limits encountered. The stratigraphic analysis of these Romanian boreholes is based on the regional Paratethyan stage concept.

On the European part of the Turkish shelf, besides DSDP boreholes, data from two TPAOTurkey Westates Petroleum exploratory boreholes (Karadeniz-1 and Iğneada-1) are available 
(Fig. 5). On these drillings (Aksü et al., 2002; Can, 1996) information is also limited to the depth (in $\mathrm{m}$ ) of the stratigraphic limits. On the base of the slope offshore the Bosporus, the seismic data were correlated with drillings 380A and 381 of DSDP Leg 42b (Fig. 5)(see section 3.1 for description). In contrast to the Romanian wells, the stratigraphical analysis of the boreholes of the European part of the Turkish margin (including the two DSDP sites) is based on the standard Mediterranean stage concept. This disparity leads us to consider two distinct study areas: the Romanian shelf on the one hand and the European part of the Turkish margin on the other hand.

\subsection{Seismic/drilling correlation}

In order to maintain coherence in the interpretation of seismic data, we chose to work with the two-way travel time sections. The stratigraphic calibration of the seismic data by the boreholes thus implied the conversion of the well depth information into travel time values. Because the in-situ measured velocities were not available for the Petrom and TPAO-Turkey Westates Petroleum boreholes, we based their depth to time conversion on our seismic stack velocities (converted in intervals velocities by mean of the Dix equation (Dix, 1955)). The use of these stack velocities has been validated using boreholes data. The stratigraphic limit depth-time correlation (computed from the in-situ measurements) was available for some of the Romanian wells. We observed only a slight average difference (6\%) between travel times computed from the in-situ measurements and the travel-times calculated from the stack velocities.

Correlation of the two DSDP cores with the seismic data is based on the velocities measured in the 380A boreholes (Ross and Neprochnov, 1978). Extrapolation of these in-situ measured velocities from well 380A to well 381 is based on the lithological correlation proposed by Hsü (1978).

\subsection{Stratigraphic scales used}

The direct biostratigraphic correlation of geological events that occurred in the Mediterranean and Eastern Paratethys during the terminal Miocene-initial Pliocene remained impossible for a long time, because the regional stratigraphic scale for the latter region was based on evolutionary succession of strictly endemic malakofauna (Chumakov, 2000; Steininger and Papp, 1979). Thus, global chronostratigraphic considerations on the Romanian shelf depended on the quality of the correlation of the Paratethyan and Standard Mediterranean scales. The discovery of periodic Mediterranean nanoplancton influxes (NN11 and NN12) in the Dacic Basin (Marunteanu and Papaianopol, 1998) and Kertch region (Semenenko and Lyul'eva, 1978) led to the recent definition of the Mio-Pliocene boundary in the Eastern Paratethys (Chumakov, 2000; Snel et al., 2006; Zubakov, 2000), which thus made possible the study over the Romanian sequences and their correlation at a global scale.

Although they are located in the Euxinic Basin (Black Sea), the Mio-Pliocene stratigraphic analysis of the Romanian boreholes (Petrom) was based on the Dacic Basin regional stages concept (Pontian, Dacian, Romanian). We thus refer for interpretation to the most recent correlation propositions between the Dacic Basin regional and Mediterranean stratigraphic scales made by Snel et al.(2006) (Fig. 6). 


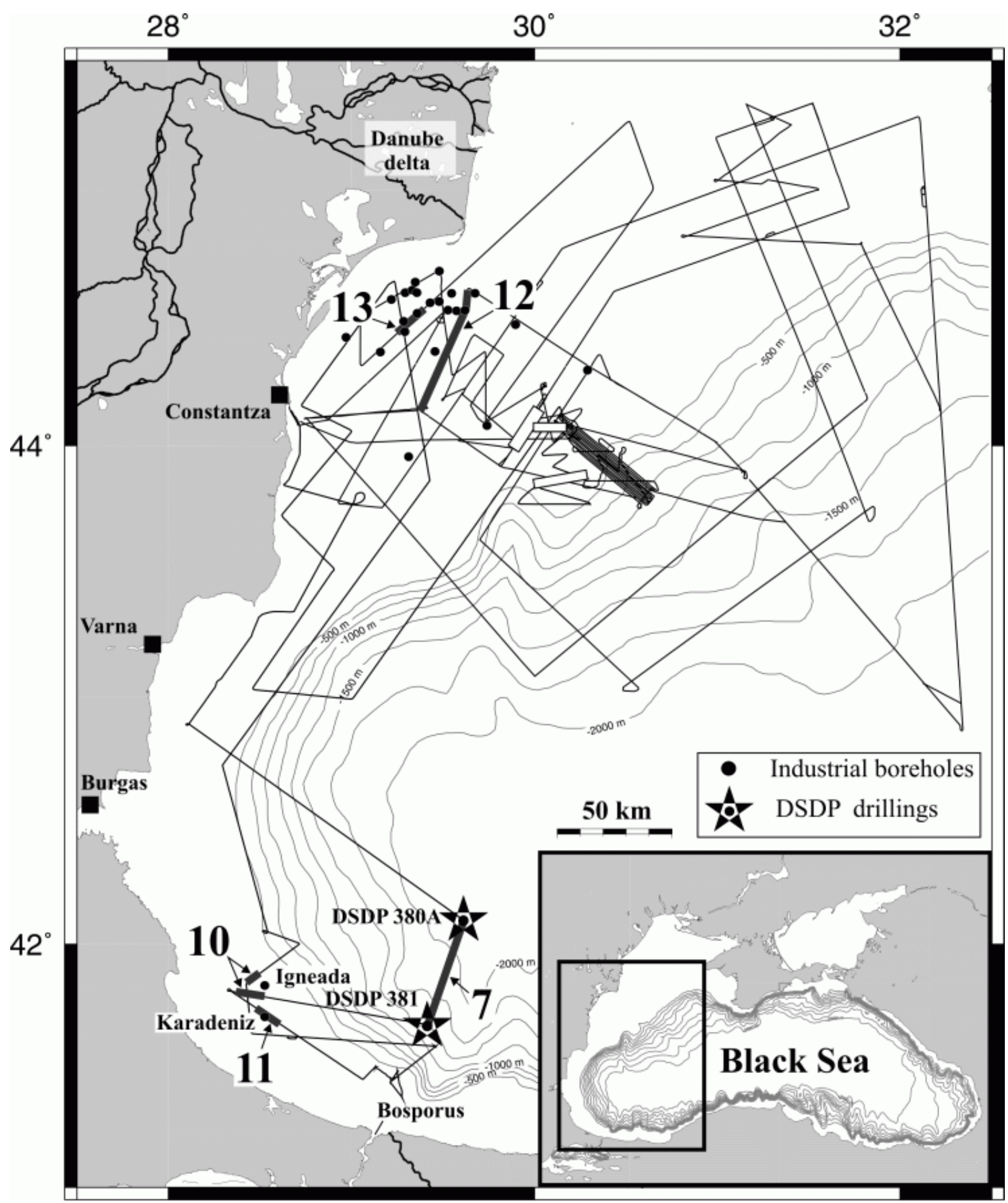

Fig. 5. Index map showing the study area, the location of the BlaSON surveys HR seismic lines (black lines) and the location on the Romanian shelf of the Petrom Company boreholes (black dots). Also are shown on the Turkish margin the locations of the DSDP sites 380A and 381 (black stars), and the TPAO-Turkey Westates Petroleum exploration wells Karadeniz-1 and Iğneada-1 (black dots). Heavy gray lines and number in figure related to figures with additional information. 


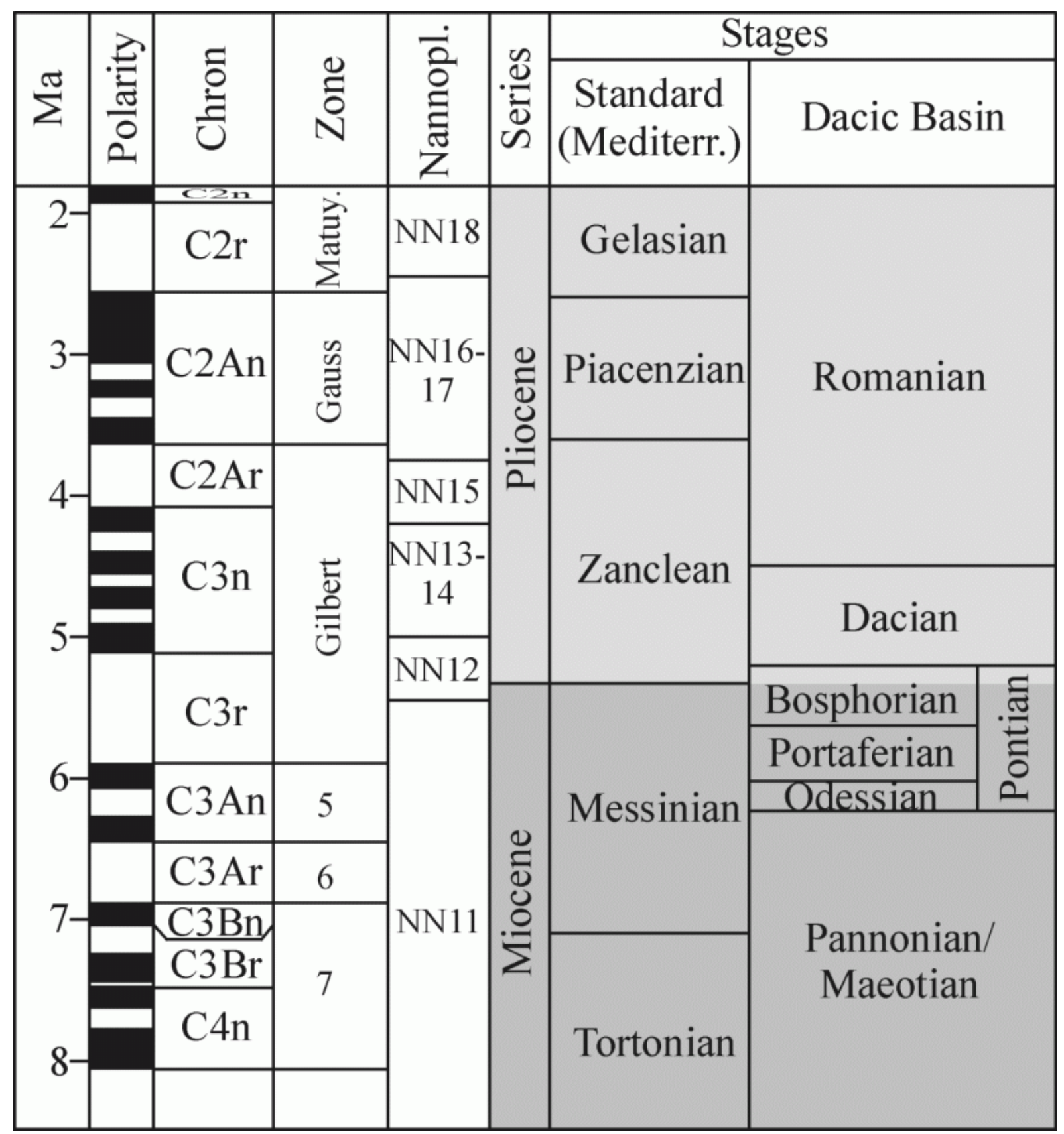

Fig. 6. Late Miocene - Pliocene chronostratigraphic relationships between the standard Mediterranean and the Regional Paratethyan (Dacic Basin) stratigraphic scales revised by Snel et al. (2006). The Regional Pontian stage overlaps the Mio- Pliocene boundary. This proposition of correlation is used in the present work. 


\section{Evidences for a Messinian Erosional Surface in Black Sea}

\subsection{The European part of the Turkish margin}

\subsubsection{Around the downslope DSDP sites, offshore Bosporus}

The b2.050 HR seismic line shot downslope offshore the Bosporus links the two DSDP drillings from site 380A (2107 m water depth) up to site 381 (1728 m water depth) (Fig. 7). Line b2.051, starts from site 381 and is strike oriented (Fig. 7). It crosses several submarine canyons, cutting the slope. Because of a difficult stratigraphic correlation between each interfluve, the proposed interpretation of this line is restricted to the neighborhood of site 381 . Correlation between the seismic lines and the drillings led to the identification of two major stratigraphic units: a Plio-Quaternary unit unconformably overlying a Miocene unit. Correlation of well DSDP 381 with line b2.050 shows that the top of the Late Miocene detritico-evaporitic unit (unit 6) correlates with a clear erosional surface (Fig. 7 and 8). This erosional discontinuity corresponds to a strong amplitude reflector ( $\mathrm{M}$ reflector) underlined by several erosional truncations. The morphology of this surface is marked by many secondary order incisions. This surface is sealed by the overlying lowermost Zanclean aragonitic mud (unit 5)(Popescu, 2006)(Fig. 2) thus inevitably dating the underlying erosional surface of the Messinian Crisis time (Fig. 8). Down-slope of site DSDP 381 along line b2.050, the Messinian erosional surface extends seaward down to the Black Sea basin (Fig. 7). Although the corresponding $\mathrm{M}$ reflector becomes more and more discontinuous, the Messinian erosional surface can be easily identified down to $750 \mathrm{~ms}$ under the sea-floor (15 $\mathrm{km}$ up-slope of DSDP site 380A), because this high impedance reflector strongly contrasts with the surrounding low energy deep acoustic facies. Deeper, identification of the Messinian erosional surface is difficult (Fig. 7). At site 380A, the top of Unit IVd does not correlate with any meaningful reflector. It seems that erosion does not reach the location of this deep drilling site, or that it was too weak to give a strong answer on the seismic data. However, prolongation of this surface along the same slope, down to site 380 suggests a good correlation between the Messinian surface and the top of this shallow water environment unit.

\subsubsection{The European part of the Turkish shelf}

Two exploration wells provide the stratigraphy for this southwestern part of the Black Sea shelf. Karadeniz-1 and Iğneada-1 were drilled at 79 and $85 \mathrm{~m}$ water depth, and are 2597 and 3118 m long, respectively (Aksü et al., 2002; Can, 1996) (Fig. 9). Karadeniz-1 recovered a very thin veneer of unconsolidated muds of Quaternary age, unconformably overlying a 107m-thick package of mudstone interbedded with shelly horizons of Pliocene age. The Pliocene deposits, in turn, unconformably overlies $1386 \mathrm{~m}$ of prograded deltaic mudstones, sandstones and conglomerates of late Oligocene-early Miocene to middle Miocene age (Can, 1996). The Iğneada-1 well recovered a 140-m-thick northward prograding Quaternary succession, unconformably overlying a 284-m-thick Pliocene shallow marine succession of mudstones with shelly horizons. The Pliocene deposits unconformably overlies $1380 \mathrm{~m}$ of prograding deltaic mudstones, sandstones and conglomerates of late Oligocene-early Miocene to middle Miocene age (Can, 1996). In both wells, the Pliocene systematically unconformably overlies the middle Miocene series evidencing a correlative stratigraphic hiatus, which spans the whole Upper Miocene. Correlation between both hiatus is confirmed by seismic data analysis.

Correlation of both boreholes Karadeniz-1 (Fig. 11) and Iğneada-1 (projected)(Fig. 10) with the BlaSON HR seismic lines allowing the identification of the Miocene, Pliocene and 


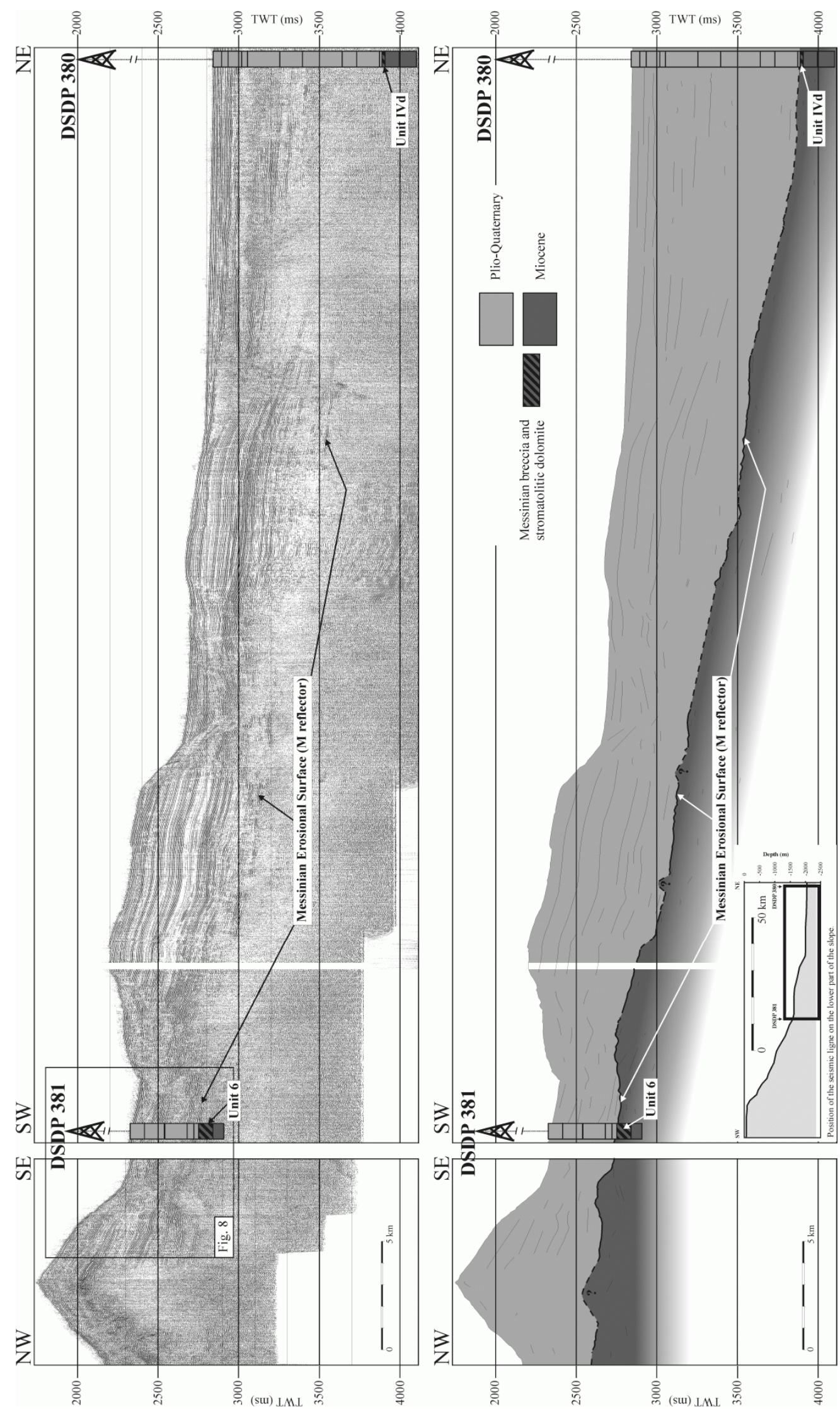

Fig. 7. Correlation between the DSDP sites 380A and 381 and the HR seismic line b2.050 (deep) and b2.051 (strike), down the slope offshore the Bosporus. The Messinian Erosional Surface correlates with the top of the Unit 6 at site DSDP 381. Although the Messinian Erosional Surface is identified downslope of site 381 down to $3500 \mathrm{msec}$, it seems that erosion does not reach 380A. See figure 5 for location of the seismic lines. 


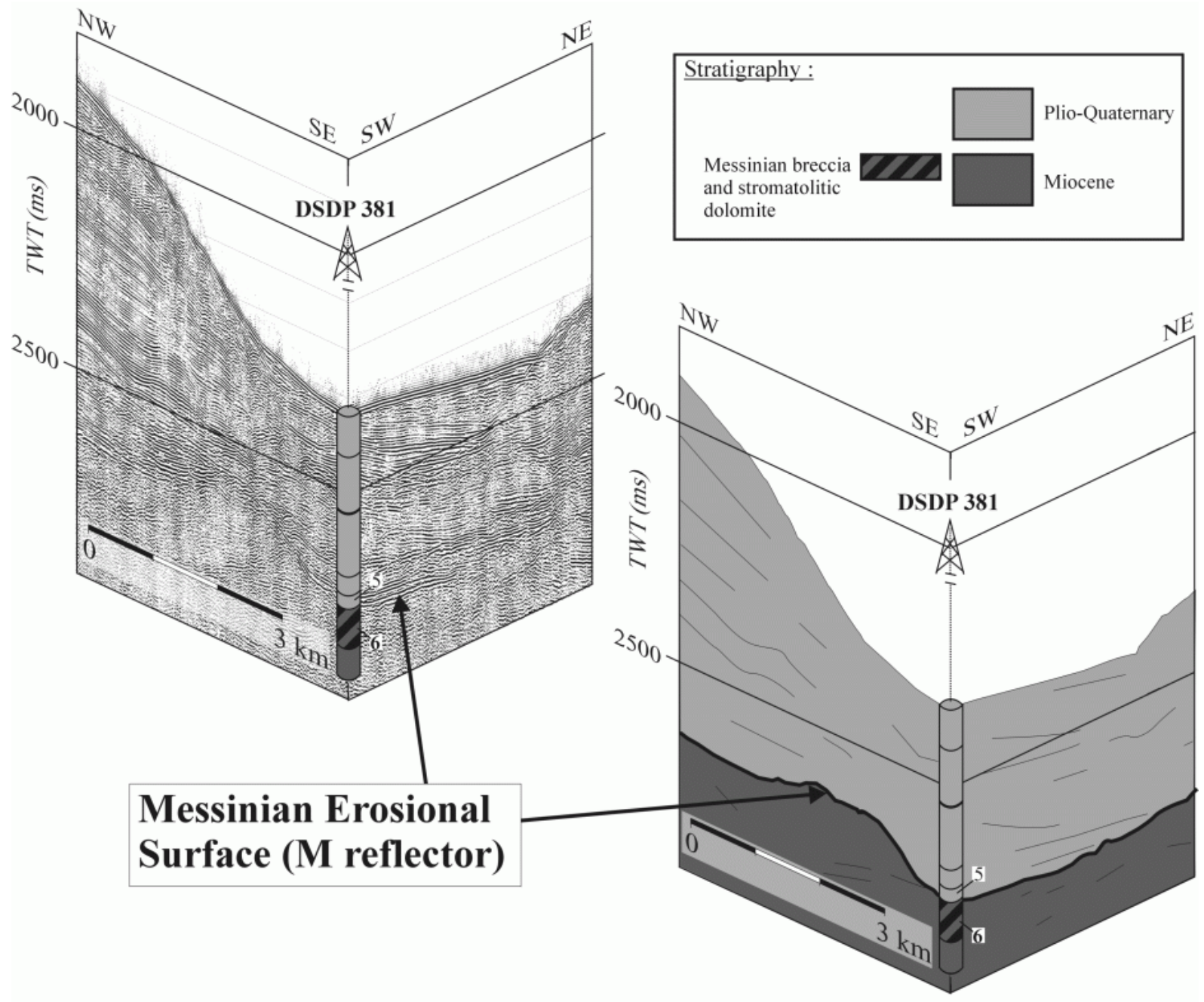

Fig. 8. Zoom on the correlation of the top of unit 6 (site 381) with the Messinian erosional surface (seismic lines b2.050 and 051). Unit 6 consists of a Messinian age breccia containing stromatolitic dolomite clasts. The erosional surface is sealed by unit 5 of site 381 which consists of aragonitic mud Lower Pliocene in age. See fig. 7 for location. 


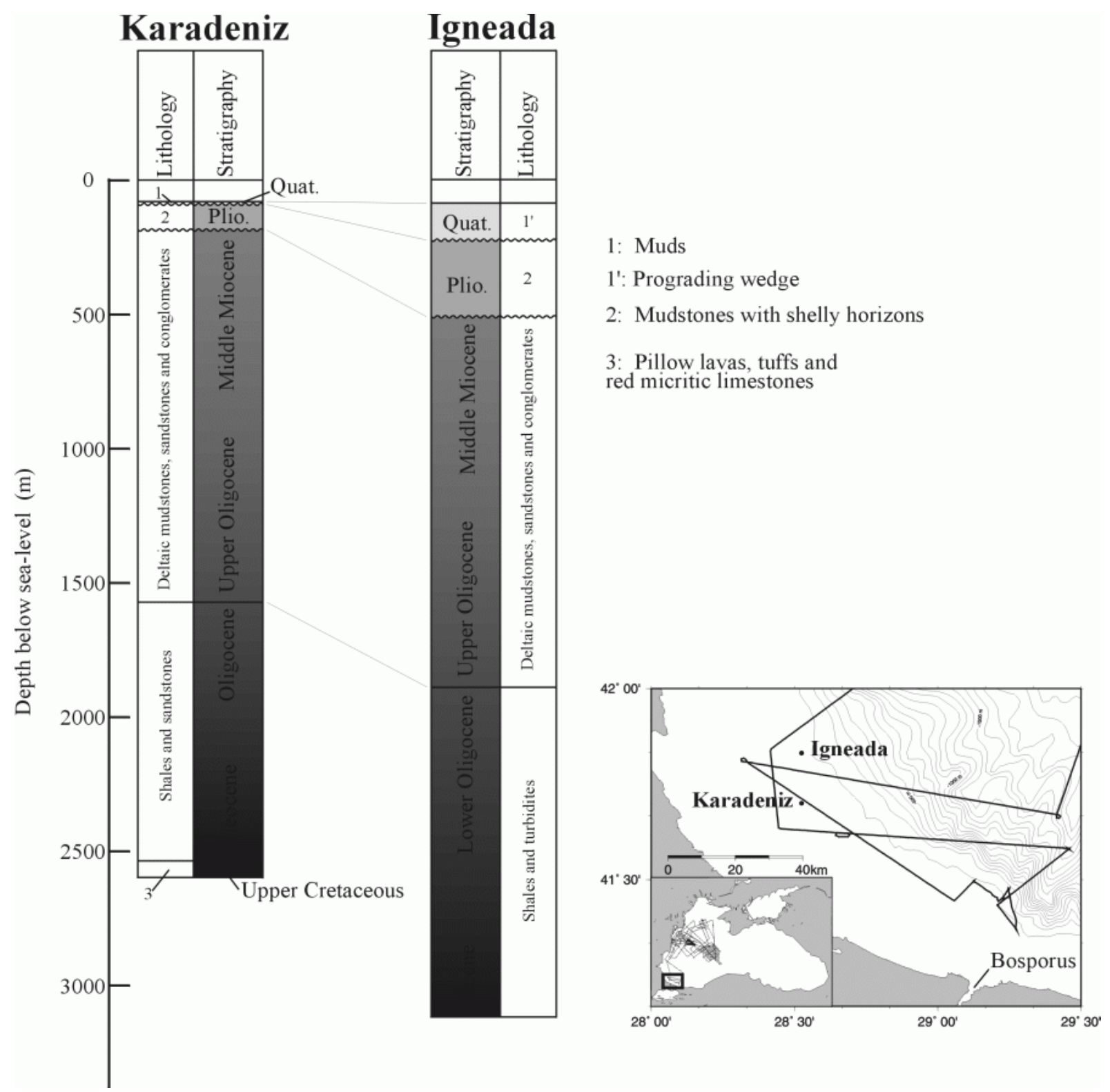

Fig. 9. Stratigraphy and lithology of the Karadeniz-1 and Iğneada-1 exploration boreholes on the European part of the Turkish margin, after Can (1996) and Aksü et al. (2002). 

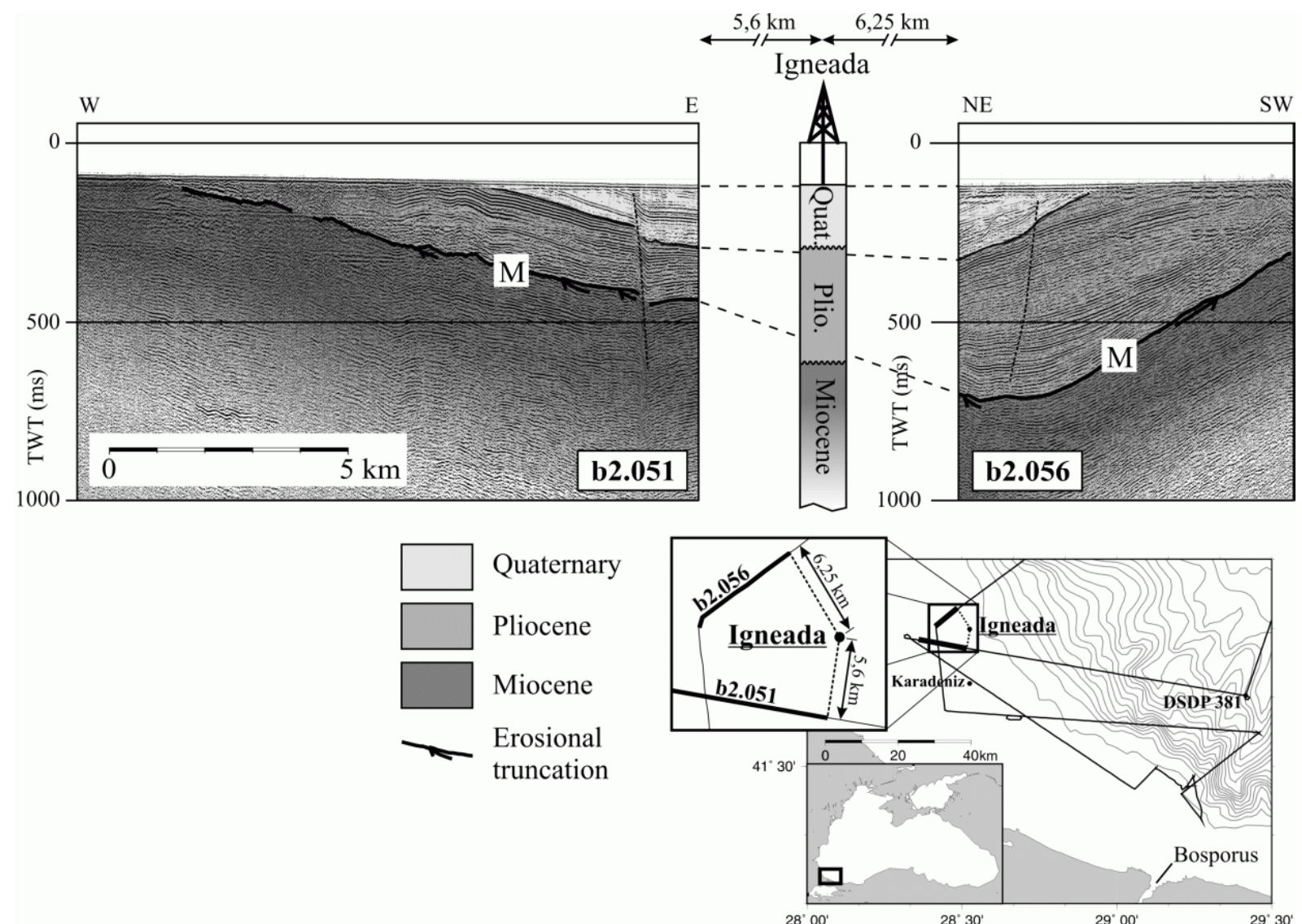

Fig. 10. Correlation between the Iğneada-1 borehole and the HR seismic lines b2.051 and b2.056. M reflector correlates with the Mio-Pliocene boundary and is interpreted as the Messinian Erosional Surface (discussed in text, see 6.1). This surface is overlain by a Pliocene prograding unit.

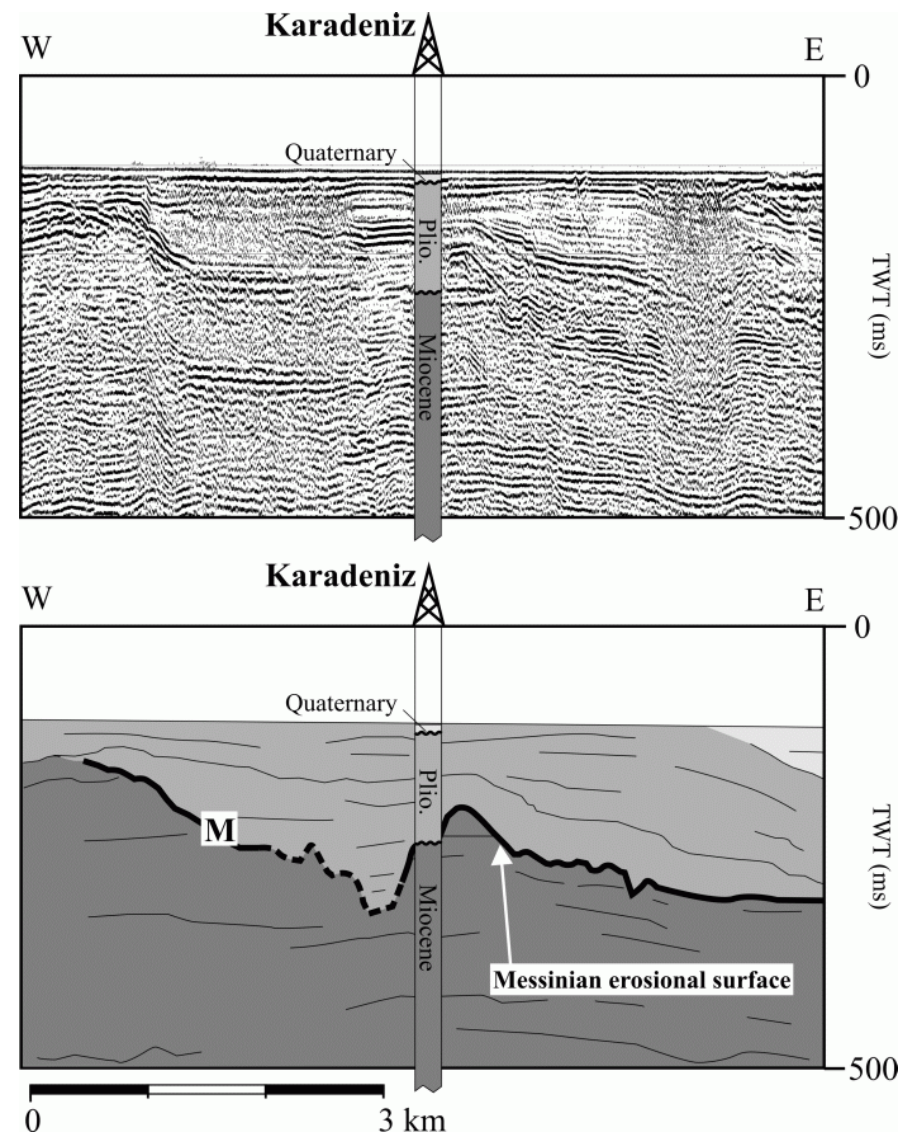

Fig. 11. Correlation between the Karadeniz-1 borehole and the HR seismic line b2.052. M reflector underlines the Messinian Erosional Surface (discussed in text, see 6.1) which is clearly erosional on this part of the margin. See figure 5 for location of the seismic profile. See Fig. 10 for Quaternary, Pliocene and Miocene shading. 
Quaternary stratigraphic units. These sedimentary series show a strong basinward dip (Fig. 10) that may be related to the combination of the Neogene Pontides-Balkanides uplift (Nikishin et al., 2003; Sinclair et al., 1997) and an acceleration of the basin subsidence during the Plio-Quaternary (Nikishin et al., 2003). As a result of this tectonic tilt, the Miocene strata are outcropping on the inner shelf (Fig. 10). On the seismic profiles, we evidence a major erosional unconformity at the top of the Miocene sequence. This seismic discontinuity is underlined by the strong amplitude $\mathrm{M}$ reflector which tangentially cuts the underlying intraMiocene reflectors generating numerous erosional truncations (Fig. 10). This erosional surface correlates with the Upper Miocene hiatus shown in the Iğneada-1 well (Fig. 10).

The direct correlation of the Karadeniz-1 borehole with the line b2.052, located on the middle shelf, supports the previous interpretation (Fig. 11). Here, the Miocene-Pliocene discontinuity evidenced in the borehole correlates with an erosional surface clearly visible on the HR seismic line. This erosional discontinuity corresponds to a discontinuous strong acoustic impedance reflector ( $\mathrm{M}$ reflector), truncating the underlying Miocene reflectors. This erosional surface is rugged and displays locally high relief. Westward of the drilling site, it defines a local incision that reaches $100 \mathrm{~ms}$ in depth in this area.

Seismic profile analysis thus clearly shows that the stratigraphic hiatus encountered at the Miocene-Pliocene boundary in boreholes Karadeniz-1 and Iğneada-1 has an erosional origin, and does not results from a lag deposit. Moreover, despite less accurate chronostratigraphic calibration, this single Mio-Pliocene boundary erosional surface can be chronostratigraphicaly correlated with the Messinian erosion observed downslope on site DSDP 381 (section 5.1.1).

\subsection{The Romanian shelf}

In contrast to most of the shelves of the Black Sea which are relatively narrow, the Romanian shelf is wide. The post-rift sedimentation of this shelf consists of a stack of five major stratigraphic units (Eocene, Oligocene, Badenian-Sarmatian, Pontian, DacianRomanian-Quaternary), which geometries are strongly influenced by the morphology of the underlying rifting structures. The four oldest units are bounded below by erosional unconformities (Gillet et al., 2003; Robinson et al., 1996) reaching a maximum depth along the axis of the Histria Depression (Gillet, 2004; Gillet et al., 2003), an asymmetric half-graben opened on the Western Black Sea basin (Dinu et al., 2005).

The most recent propositions for the correlation between the Regional Dacic and Mediterranean stratigraphic scales states that the Regional Pontian stage overlaps the MioPliocene boundary (Snel et al., 2006) (Fig. 6). We thus concentrated our research on the Pontian stratigraphic unit and evidenced the presence of a major intra-Pontian seismic discontinuity, splitting the Pontian into two distinct sub-units (P1 and P2). This Intra Pontian Unconformity (IPU) corresponds to a major erosional surface with atypical characteristics.

Firstly, in contrast with usual high amplitude seismic signature of an erosional surface, the IPU corresponds to an alignment of low-energy discontinuous reflectors (Fig. 12). It is underlined essentially by the numerous erosional truncations affecting the subparallel reflectors of the underlying unit P1 which is characterized by high frequency and strong amplitude subparallel reflectors with relatively good lateral continuity. In addition, a strong acoustic facies contrast is visible between P1 and the overlying unit P2 which consists of a low-energy acoustic facies characterized by discontinuous low amplitude reflectors showing however some scattered seaward prograding clinoforms (Fig. 12).

Secondly, the IPU erosional surface is characterized by a limited regional extension (approximately $13400 \mathrm{~km}^{2}$ over the study area) and by a sharp decrease of incision rate from outer to inner shelf. On a wide half part of the outer-shelf, the IPU corresponds to a set of deep incisions (canyons) (Fig. 12). Their lateral extension is limited to a $150 \mathrm{~km}$ wide 
corridor plumb with the Histria Depression suggesting a deep tectonic control on the morphology of the IPU. On the distal seismic lines, this erosional surface slopes down below the penetration depth of our HR seismic. Strike line BlaSON b010 (Fig. 12) shows some IPU canyons reaching $550 \mathrm{~m}$ depth (using a $2200 \mathrm{~m} / \mathrm{s}$ interval velocity). Nevertheless, none of the described canyons extend landward on the inner-shelf and accordingly none of these deep incisions reache the modern coastline position. Indeed, canyon erosion stops abruptly some kilometres landward of line BlaSON b010. On the inner-shelf, the set of deep incisions gives place to a superficial incisions network (Fig. 13). These superficial incisions (50 m deep at most) occur on a corridor spreading from the deep incisions zone to the location of the modern Danube delta (Fig. 14). The seaward prograding clinoforms of the sub-unit P2 illustrate the rapid clastic sediment filling of the space made available by the IPU erosion phase.

The fact that the IPU is contained in the Pontian sequence allows us to narrow down the potential time window for its formation to 6.25-5.2 Ma. Because this time interval contains the Miocene/Pliocene boundary, we propose that this erosional surface potentially corresponds to the Romanian shelf analogue of the Messinian erosional surface evidenced offshore the Bosporus on site DSDP 381 (section 5.1.1). 


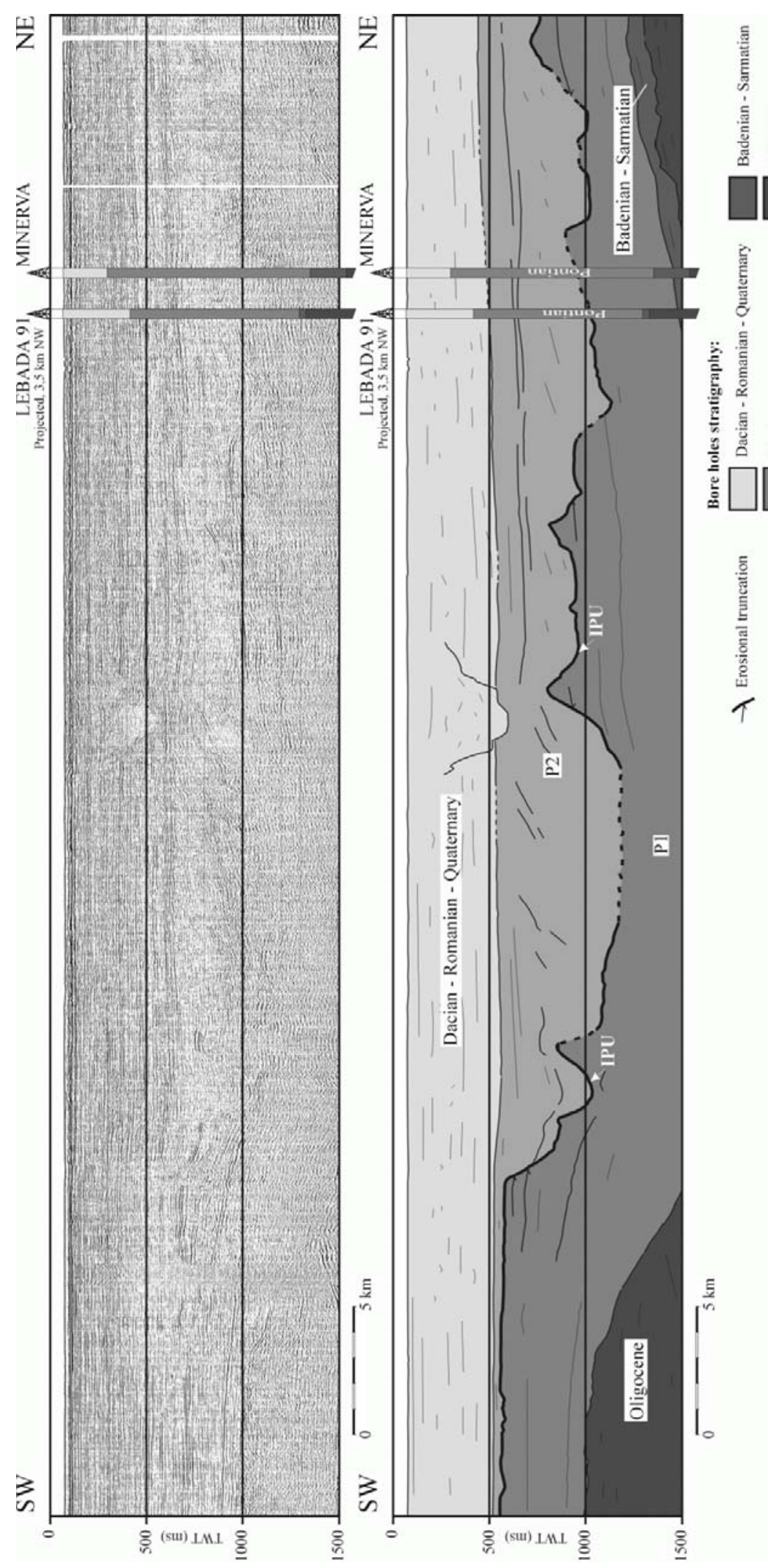

Fig. 12. HR seismic line b.010 on the Romanian shelf and its interpretation. Lebada and Minerva boreholes (Petrom Company) allowed stratigraphic calibration of this line. A major erosional surface (IUP) splits the Pontian series into two distinct sub-units (P1 and P2) and corresponds here to a set of deep incisions (canyons). According to the most recent Paratethyan and Mediterranean stratigraphic scales (Snel et al., 2006), we propose that the IPU surface corresponds to the Messinian Erosional Surface on the Romanian shelf (discussed in text, see 6.1). See figure 5 for location of the seismic profile. 

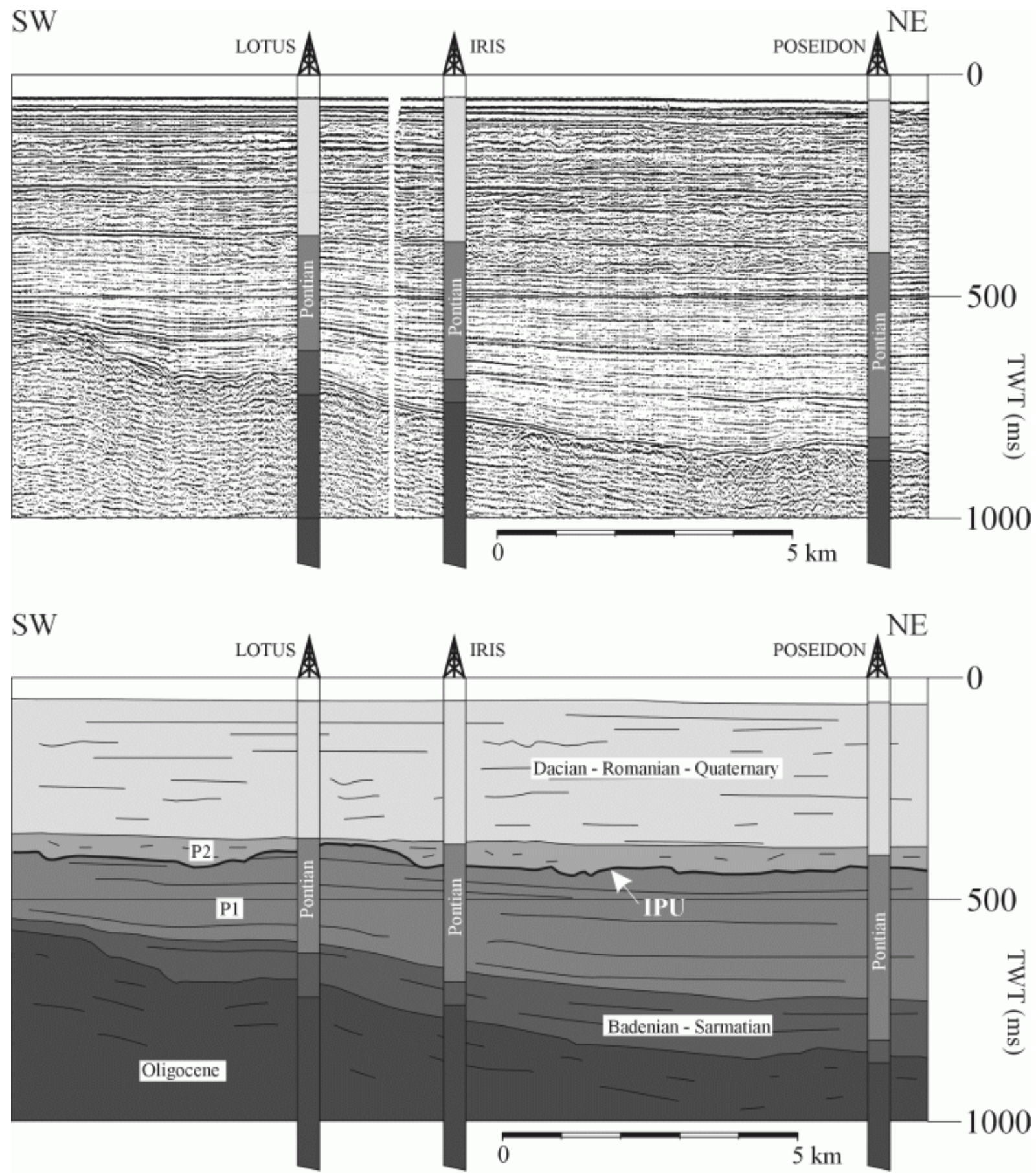

Bore holes stratigraphy:
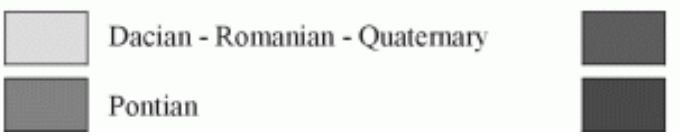

Badenian - Sarmatian

Oligocene

Fig. 13. HR seismic line b.080 on the inner Romanian shelf and its interpretation. The IPU erosional surface splits the Pontian series into two distinct sub-units (P1 and P2) and corresponds here to a superficial incision network. Lotus, Iris and Poseidon boreholes (Petrom Company) allowed stratigraphic calibration of the line. According to the most recent Paratethyan and Mediterranean stratigraphic scales correlation (Snel et al., 2006), we consider the IPU surface as the Messinian Erosional Surface on the Romanian shelf (discussed in text, see 6.1). See figure 5 for location of the seismic profile. 

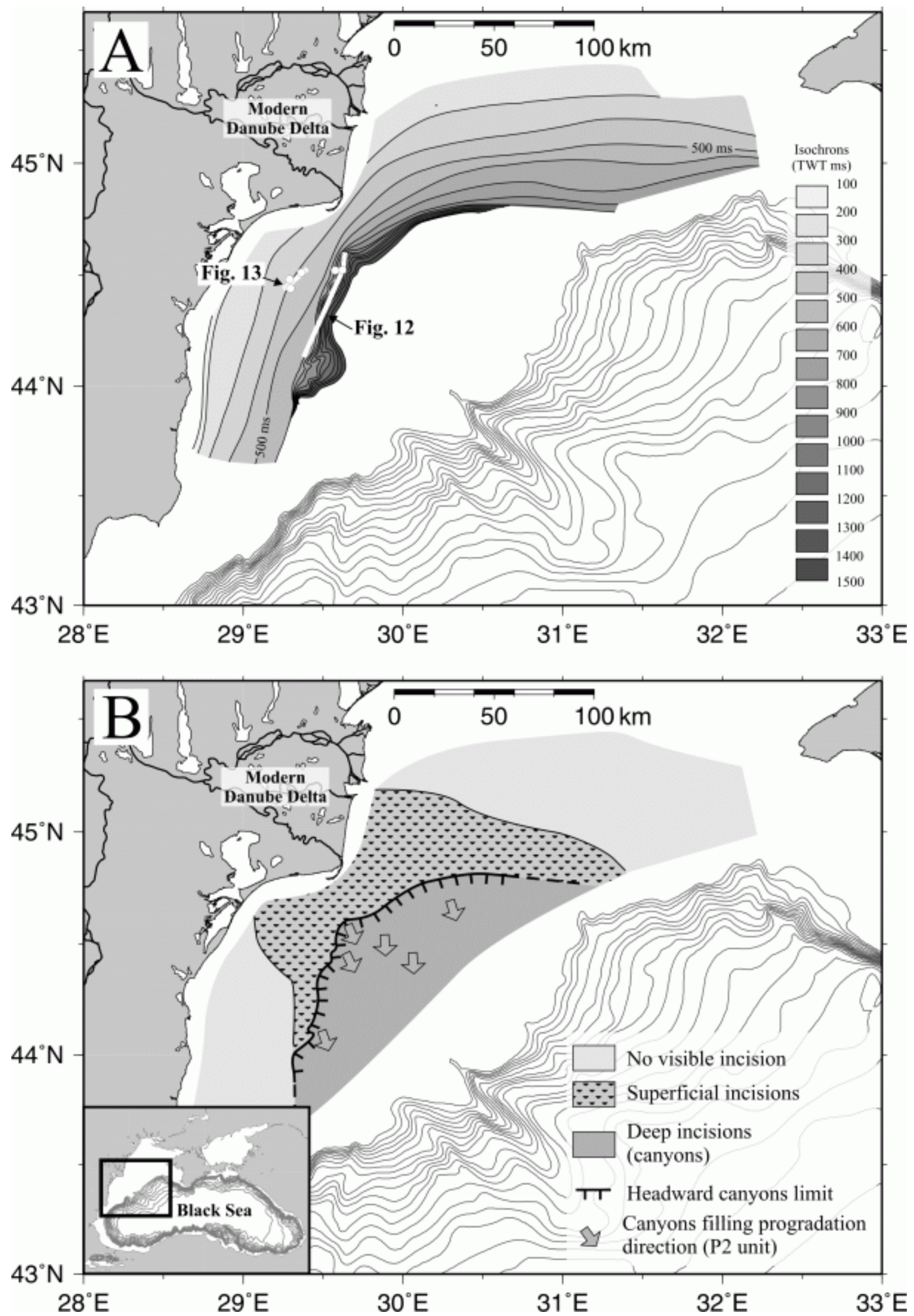

Fig. 14. A. Isochron map of the IPU erosional surface on the Romanian shelf; B. Morphologic map showing that the IPU is characterized by a sharp decrease of incision rate from outer (deep canyons) to inner shelf (superficial incisions network). White lines on A refer to seismic lines presented on Fig. 12 and 13. White dots refer to industrial drill holes used to calibrate these seismic lines. 


\section{Discussion}

\subsection{Validation of the Black Sea desiccation hypothesis}

From reanalysis of the lithology of DSDP sites 380A and 381, improved with high resolution seismic data acquired during the BlaSON surveys, we arrive at the following observations:

(1) On DSDP site 381, the Messinian erosional surface evidenced on the seismic lines correlates with the top of the Late Miocene detritico-evaporitic unit (Unit 6) (Fig. 8) presenting shallow depositional environment and evidences for occasional subaerial exposure and meteoric diagenetism (Stoffers and Müller, 1979). These observations imply (at least in this area) a subaerial origin for the Messinian erosional surface. In addition, the deeper water sediments recovered below and above unit 6 suggest that this surface has been created during a temporary lowering in sea-level (Hsü and Giovanoli, 1979). This is in accordance with the presence of Messinian autochtonous shallow water sediments (Unit IVd of DSDP 380A) downslope of the Messinian erosional surface (

Fig. 7). This observation confirms the subaerial origin of the erosional surface located more upslope of site DSDP 380A. Detritic breccias, including stromatilitic dolomite clasts, recovered in Unit 6 (site 381) and IVd (site 380A) would than correspond to the coarser clastic products issued from the subaerial erosion.

(2) Using a subsidence model for the Black Sea basin, Nikishin et al. (2003) propose that the water depth was $2250 \mathrm{~m}$ in the Black Sea Western basin in Late Miocene time. Both arguments (subaerial origin of the downslope erosional surface and pre-existing deep basin) support the hypothesis of Hsü and Giovanoli (1979), who proposed that these Late Miocene shallow water sediments (Unit 6 and IVd) were deposited in a pre-existing deep basin partially desiccated at the end of the Messinian.

(3) The presence of the Messinian erosional surface at the top of the Unit 6 at site 381 (

Fig. 7 and 8) demonstrates that these sediments have been exunded after their deposition in a shallow water environment. However, at site 380A, the erosional surface is not visible (

Fig. 7), suggesting that this site was not exunded, but probably remained under shallow water conditions as it is testify by the stromatolitic dolomite of Unit IVd. This is in agreement with the work of Stoffers and Müller (1979) who have proposed that (a) Unit 6 (site 381) was deposited in shallow water conditions before the maximum drop of the sea level, when at the same time site 380A was in a deeper environment, (b) the deposition of Unit IVd at site 380A in shallow water environment illustrates the maximum drop of the sea level drop implying exundation of site 381 and subaerial erosion at the top of Unit 6.

(4) The above interpretations are also supported by the discoveries made on the Turkish and Romanian shelf respectively. The presence of present-day canyons on the Turkish slope makes impossible the direct correlation between the seismic lines acquired on the Turkish shelf and the lithological logs of the deep DSDP sites. However, the presence of a major erosional surface at the Miocene-Pliocene boundary in neighborhood of Karadeniz-1 and Iğneada-1 drillings (Fig. 10 and Fig. 11) support the concept of the creation of a generalized erosional surface at the scale of the Black Sea basin during the Messinian. We thus consider this erosional surface as the analogue on the European part of the Turkish shelf of the Messinian Erosional Surface discovered on the base of the slope between DSDP sites 380A and 381 (Fig. 7). Similarly, the correlation by the way of HR seismic lines between the Romanian and Turkish margins was impossible due to the wide occurrence of shallow gas and related acoustic masking on the Bulgarian shelf. So, the partial Messinian desiccation of the Black Sea demonstrated on the Turkish margin should have an analogue surface of erosion 
along the entire Black Sea margin, including the Romanian one. According to the most recent Paratethyan and Mediterranean stratigraphic scales correlation (Snel et al., 2006) (Fig. 6), we consider the IPU erosional surface pointed out on the Romanian shelf (Fig. 12, Fig. 13 and Fig. 14) as the expected analogue of the Messinian Erosional Surface previously described on the European part of the Turkish margin (shelf and slope). The tectonic stability of the Romanian shelf during Tertiary-Quaternary times (Robinson et al. 1996), suggests a eustatic origin rather than tectonic origin.

To summarize, we evidence the existence of a wide regional Messinian erosional surface on the Western Black Sea margins supporting the previously incomplete argumentation for the Messinian draw-down in the Black Sea: the deep basin shallow water sediments described by Stoffers and Müller (1979), the inland erosional and delayed signature of Clauzon et al.(2005) (Fig. 4) and pre-existing deep basin interpreted by Nikishin et al. (2003) and Robinson et al. (1995). Our results confirm the hypothesis of a drastic lowering of the waterlevel within the Black Sea basin at the end of the Messinian (Hsü and Giovanoli, 1979).

\subsection{About the origin of the Black Sea Messinian event}

Although the presence of a Messinian erosional surface is in accordance with the hypothesis of Hsü and Giovanoli (1979), some details of this model do not match the recent discoveries made in the Dacic basin (Clauzon et al., 2005). Indeed, Hsü and Giovanoli (1979) proposed that the evaporative Messinian draw-down of the Black Sea was related to the capture of the central Europe Danube waters towards the "desiccated" Mediterranean basin. Clauzon et al. (2005) nevertheless demonstrate that the Danube has been captured during the Messinian towards the Eastern Paratethys. . They also demonstrate that the proto-Danube did not flow into Eastern Paratethys (including Dacic and Black Sea basins) before the Messinian event. . The lower course of this proto-Danube was restricted to the Pannonian Basin. Thus, a hypothetical deviation of the course of this proto-Danube cannot have had any consequences on the hydraulic budget of the eastern Paratethys and cannot be the factor that resulted in the Messinian draw-down of the Black Sea. According to this argument, this part of the model of Hsü and Giovanoli (1979) must be rejected.

The evaporative Messinian draw-down of the Black Sea implies: (1) the isolation of the basin and (2) persistence or installation of a negative hydraulic budget in which evaporation exceeds basin water inputs.

The Messinian isolation can be easily explained by the analysis of the paleogeographic situation. In the Late Miocene time, the Eastern Paratethys isolated from other parts of the world ocean, was connected to the Mediterranean realm by a shallow sill north of the Aegean Sea (Meulenkamp and Sissingh, 2003; Rögl, 1999). The record of NN11 influx in the Eastern Paratethys (Marunteanu and Papaianopol, 1998, Semenenko and Lyul'eva, 1978) demonstrates that such connections persisted until Late Messinian time (Clauzon et al, 2005). Then, at the end of the Messinian, the evaporative draw-down of the Mediterranean Sea resulted in the complete isolation of the Eastern Paratethys (including Black Sea basin) behind the North-Aegean sill.

Persistence or installation of a negative hydraulic budget in this basin must thus be discussed. Paleoenvironmental studies demonstrate that in the Late Miocene time, just before the Messinian Salinity Crisis, the Eastern Paratethys was characterized by reduced salinity environment (Papaianopol and Marinescu, 1995; Papp et al., 1974; Rögl, 1999; Semenenko and Lyul'eva, 1978; Steininger and Papp, 1979). Persistence of reduced salinity in the Eastern Paratethys along with a context of connection with the Mediterranean realm implied a positive hydraulic budget restricting the Mediterranean marine water intakes. It also means that the Messinian evaporative draw-down of the Black Sea following isolation of the basin 
implied a sudden change from positive to negative hydraulic budget in the Late Messinian time. We propose the following working hypothesis to explain this sudden change.

The installation of a negative hydraulic budget in this basin in Late Messinian time could be related to a drastic climatic change. Such climate change could be the result of the partial desiccation of the Mediterranean Sea, as the disappearance of an epicontinental sea can influence global atmospheric circulation. This is in accordance with Steininger and Papp (1979) who proposed that the marked increase of open country type mammal fauna (e.g : antelopes, hyanids and endemic African taxa) recorded on the entire Paratetyan realm resulted from a sudden change from established Lower Pontian wet-temperate climate to a distinct Upper Pontian dry phase. However, this proposition appears inconsistent with a recent highresolution pollen study showing the persistence of a warm-temperate climate (with moderated amplitude variations) on the Eastern Paratethys during the Upper Miocene-Lower Pliocene period (Popescu, 2001). Both argument are not completely in disagreement as one concerns a wide regional record (fauna migration) and the other deals with a more accurate Eastern Paratethys climatic record (Popescu study).

As another working hypothesis, we propose that the installation of a negative hydraulic budget in the basin could be related to a sudden Eastern Paratethys drainage pattern reorganization. This re-organization would result from the eustatic tuning on both sides of the North-Aegean sill following the beginning of the Messinian draw-down in the Mediterranean. As a result of the closure of Mediterranean water inputs, sea-level in the Black Sea may have temporary dropped to the depth of the sill. This may have resulted in a fragmentation of the Eastern Paratethys into several sub-basins bounded by intern sills (such as Dobrogean sill). Such a fragmentation would cause the capture of part of the water inputs of the Eastern Paratethys into marginal perched basins (such as the northeastern part of the Dacic basin (Clauzon et al., 2005)) leading to the establishment of a negative water budget in the isolated Black Sea.

Considering a climate component, a low-amplitude sea-level fall could lead to the creation of such lakes, thus bringing an increased contribution to the reduction of the water inputs to the Black Sea. Both hypotheses (climate and river pattern changes) are not incompatible.

\subsection{About the lower course of the Messinian Danube}

Clauzon et al. (2005) proposed that in the southwestern Dacic Basin the Messinian erosional surface has developed along the Danube and its mains tributaries courses, whereas the northeastern part remained as a perched lake having recorded a continuous sedimentation (Fig. 4). The complete lack of information about the Messinian paleogeography of the Eastern part of this basin leads to crucial interrogation concerning the lower course and outlet of the Messinian Danube. Our results on the Western Black Sea margin bring some important arguments that unfortunately appear contradictory: (1) complete absence of a large Messinian Danube canyon incision on the Romanian shelf, (2) presence of a Messinian superficial incision network connecting the middle shelf deep incisions zone to the location of the modern Danube delta (Fig. 14).

On the one hand, the absence in the Black Sea of a Danube analogue to the Messinian Rhône or Nile canyons supports the hypothesis of a Danube's Messinian lower course restricted to the Dacic basin (Fig. 15.A). In this hypothesis, we propose that the Messinian Danube flowed into the remnant Dacic perched lake described by Clauzon et al. (2005) and we suggest that the deep IPU incisions evidenced on the middle Romanian shelf correspond to the retrogressive subaerial erosion of the Messinian paleo-shelf break related to the installation of a Messinian coastal drainage pattern (superficial incision network) on the exunded shelf. 

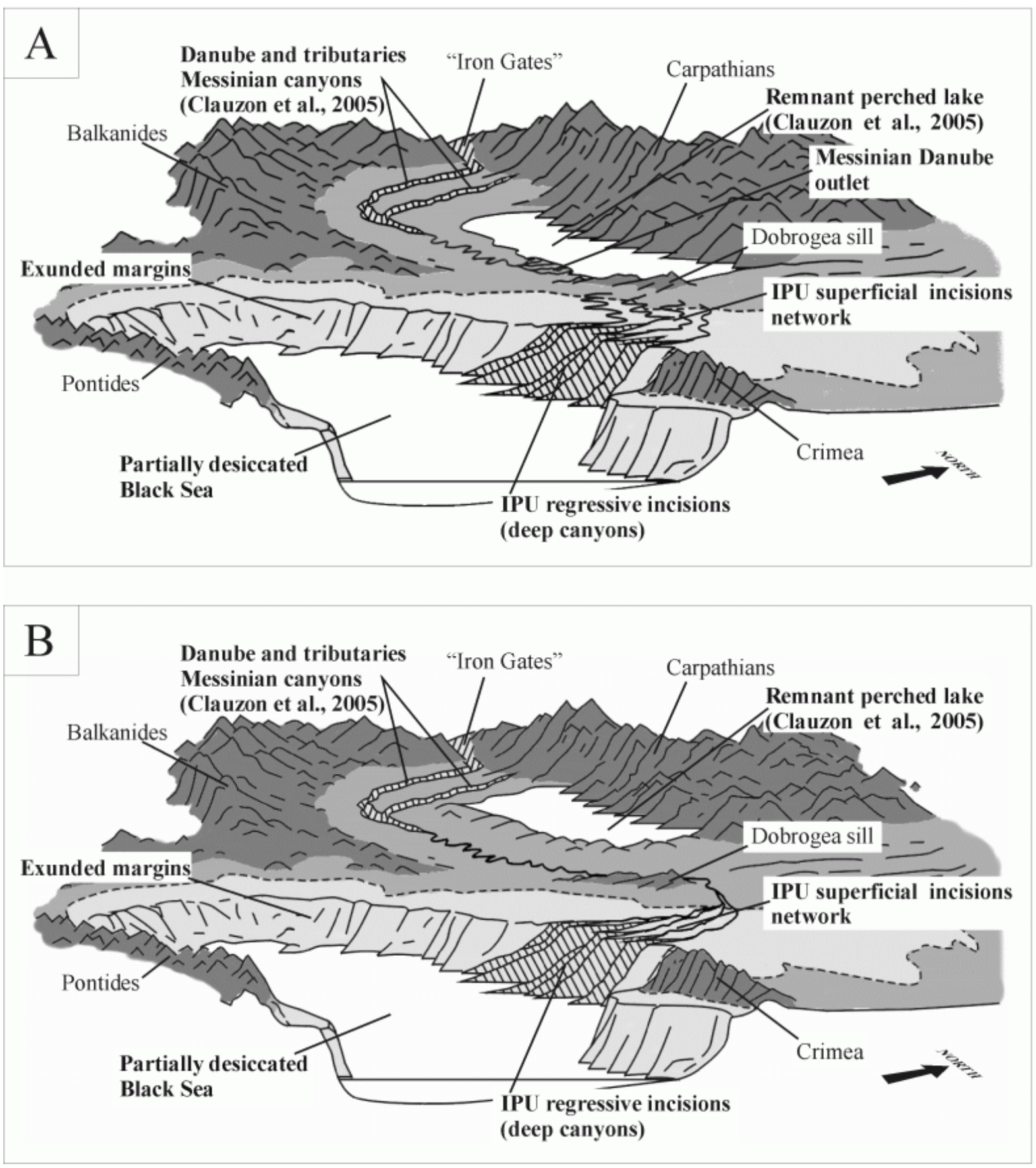

Fig. 15. Proposed working hypothesis for the lower course of the Messinian Danube: A. the Messinian Danube remained trapped in the Dacic basin during basin "desiccation"; B. the Messinian Danube was reaching the partially desiccated Black Sea. 
On the other hand, the presence of a Messinian superficial incisions network on the inner part of the Romanian shelf is not incompatible with the hypothesis of a Messinian Danube flowing into the "desiccated" Black Sea basin (Fig. 15.B). Because this network connects the location of the modern Danube delta to the middle shelf Messinian canyons, it suggests that the Messinian Danube reached the Black Sea via a similar course to its modern one. According to this hypothesis, the superficial incisions network would correspond to the Messinian anastomosed lower course of the Danube on the inner shelf, reaching down stream the very low level of the Messinian Black Sea through the described IPU canyons. However, to support such a hypothesis a major erosional canyon of the Danube on the shelf would have been evidenced instead of the restricted retrogressive subaerial erosion of the paleo-shelf break.

Analogue situation have been described for the paleo-Berre and paleo-Aude systems in the Gulf of Lions (Northwestern Mediterranean Sea)(Lofi et al, 2005). Despite the presence of two deep Aude and Berre Messinian valleys beneath the inner shelf, no related canyons are visible onshore. Lofi et al (2005) proposed that karstic resurgences may have been at the origin of the deep Messinian incisions noted on the middle shelf. On the Romanian shelf, the dominant lithology of the series eroded by the IPU canyons (Pontian series) consists of shales with rare thin sandstone beds (Robinson et al., 1996; Trambrea et al, 2002). Such karstic origin for the IPU canyon must therefore be rejected.

\section{Conclusion}

High resolution multichannel seismic reflection data acquired during the BlaSON surveys allow the recognition of a widespread Messinian erosional surface in the Black Sea on both the European part of the Turkish margin and on the Romanian shelf. In addition to former arguments describing the presence of shallow water environment sediments in the deep basin (Stoffers and Müller, 1979), the existence of a Messinian Danube canyon onland filled by Lower Pliocene Gilbert delta system (Clauzon et al., 2005) and the pre-existing deep status of the Miocene basin (Nikishin et al., 2003; Robinson et al., 1995), this new element bring the last argument that validates the hypothesis of Hsü and Giovanoli (1979). Indeed, we confirm that the Black Sea was severely affected by the Mediterranean Messinian Salinity Crisis and suffered a drastic lowering of its water-level at the end of the Messinian.

Down the slope offshore the Bosporus, the correlation between our seismic reflection data and DSDP drilling of site 381 led to the extremely accurate stratigraphic calibration of this Messinian erosional surface. Erosional truncation of the top of the Unit 6 at site 381 suggests that this site was exunded during maximum draw-down of sea-level whereas absence of such an erosional surface at the top of the Unit IVd at site 380A suggests that this deeper site never exunded and was covered by shallow water at the same time.

Because the direct standard Mediterranean stratigraphic calibration is difficult to apply to the interpreted drillings on the Romanian shelf, the identification of the Messinian erosional surface was here based on (1) the analogy between the local erosional surface (IPU) and the discovery made on the Turkish margin and (2) on the most recent proposition of correlation between the Paratetyan and Mediterranean stratigraphic scales (Snel et al., 2006).

We also demonstrate that evaporative draw-down of the Messinian isolated Black Sea implied the installation on the basin of a negative hydrologic budget. The Climatic origin and the implication of drainage changes have to be explored.

On the Romanian shelf, the Messinian erosional surface (IPU) is characterized by a sharp decrease of incision rate from outer (deep canyons) to inner shelf (superficial incisions 
network). The absence of a major Messinian Danube canyon on the Romanian shelf supports the hypothesis of a Messinian Danube which remained trapped in the Dacic basin. However, because of the presence of a superficial incision network connecting the location of the modern Danube delta to the outer shelf Messinian canyons, the hypothesis of a Danube reaching the partially desiccated Black Sea remains possible.

\section{Acknowledgements}

This PhD work was supported by a grant of the French ministry of research and prolonged by a European project of the $5^{\text {th }}$ framework program called ASSEMBLAGE (EVK3-CT2002-00090). We thank Prof. Corneliu Dinu (University of Bucharest) for providing stratigraphic information for drillings of Romanian Petrom Company and Prof. Nicolas Panin (Geoecomar), who was at the initiative of the BlaSON research projects. We thank C. Seyve and J.L. Rubino (Total), G. Clauzon (CEREGE) and J.P. Suc (Univ. Lyon 1) for fruitful discussions. We also thank First Crew of the R/V Le Suroît and then Hervé Nouzé and Estelle Théreau for assistance in seismic processing. We thank Alison Chalm, Walter Roest and Anna Pienkowski-Furze for having helped us with the English. We thank J.J. Cornée, J. Lofi and the editors for their constructive reviews and comments. This is UMR 5805 - EPOC contribution $n^{\circ} 1666$.

\section{References}

Aksü, A.E., Hiscott, R.N., Yasar, D., Isler, F.I. and Marsh, S., 2002. Seismic stratigraphy of Late Quaternary deposits from the southwestern Black Sea shelf: evidence for noncatastrophic variations in sea-level during the last 10 000 yr. Mar. Geol., 190(1-2), 61-94.

Can, E., 1996. Tectonic evolution of the Southwestern Black Sea Margin, offshore Turkey. Unpublished M.Sci. Thesis, Texas, A\&M University, 88 pp.

Chumakov, I.S., 1973. Pliocene and Pleistocene deposits of the Nile Valley in Nubia and Upper Egypt. In: W.B.F. Ryan et al. (Editors), Int. Repts. DSDP, 13 (part 2). U.S. Govt. Printing Office, Washington, D.C., pp. 1242-1243.

Chumakov, I.S., 2000. The problem of the Miocene-Pliocene boundary in the Euxinian region. Stratigr. Geol. Correl., 8(4), 396-404.

Clauzon, G., 1973. The eustatic hypothesis and the pre-Pliocene cutting of the Rhone Valley. In: W.B.F. Ryan et al. (Editors), Int. Repts. DSDP, 13 (part 2). U.S. Govt. Printing Office, Washington, D.C., pp. 1251-1256.

Clauzon, G., Rubino, J.L. and Savoye, B., 1995. Marine Pliocene Gilbert type fan deltas along the French Mediterranean coast. Field trip guide book, 16th IAS regional meeting Sedimentology. Publ. Ass. Sed. Fr. 23, pp. 143-222.

Clauzon, G., Suc, J.P., Popescu, S.M., Marunteanu, M., Rubino, J.L., Marinescu, F. and Melinte, M.C., 2005. Influence of Mediterranean sea-level changes on the Dacic basin (Eastern Paratethys) during the Late Neogene : the Mediterranean Lago Mare facies deciphered. Basin Res., 17(3), 437-462.

Dinu, C., Wong, H.K., Tambrea, D. and Matenco, L., 2005. Stratigraphic and structural characteristics of the Romanian Black Sea shelf. Tectonophysics 410 (1-4), 417-435

Dix, C.H., 1955. Seismic velocities from surface measurements. Geophysics 20, 68-86.

Drivaliari, A., Ticleanu, N., Marinescu, F., Marunteanu, M. and Suc, J.P., 1997. A Pliocene climatic record at Ticleni (southwestern Romania). In: J.H. Wrenn, J.P. Suc and S.A.G. Leroy (Editors), The Pliocene: time of change. American Association of Stratigraphic Palynologists Foundation, pp. 103-108. 
Finetti, I., Bricchi, G., Del Ben, A., Pipan, M. and Xuan, Z., 1988. Geophysical study of the Black Sea. Boll. Geofis. Teor. Appl., 30(117-118), 197-324.

Gheorghian, M., 1978. Micropaleontological investigations of the sediments from sites 379, 380 and 381 of leg 42B. In: D.A. Ross and Y.P. Neprochnov (Editors), Int. Repts. DSDP, 42 (part 2). U.S. Govt. Printing Office, Washington, D.C., pp. 783-787.

Gillet, H., 2004. La stratigraphie tertiaire et la surface d'érosion messinienne sur les marges occidentales de la mer Noire : Stratigraphie sismique haute résolution. Tertiary stratigraphy and Messinian erosional surface on Western Black Sea margins : High Resolution Seismic Stratigraphy, PhD Thesis, Université de Bretagne Occidentale (Brest - France), 259 pp.

Gillet, H., Lericolais, G., Réhault, J.P. and Dinu, C., 2003. La stratigraphie oligo-miocène et la surface d'érosion messinienne en mer Noire, stratigraphie sismique haute résolution. The Oligo-Miocene stratigraphy and the Messinian erosional surface in Black Sea, high-resolution seismic stratigraphy. C.R. Geosci.. 335(12), 907-916.

Guennoc, P., Gorini, C. and Mauffret, A., 2000. Histoire géologique du Golfe du Lion et cartographie du rift oligo-aquitanien et de la surface messinienne. Géologie de la France 3, 67-97.

Hsü, K.J., 1978. Correlation of Black Sea sequences. In: D.A. Ross and Y.P. Neprochnov (Editors), Int. Repts. DSDP, 42 (part 2). U.S. Govt. Printing Office, Washington, D.C., pp. 489-497.

Hsü, K.J., Cita, M.B. and Ryan, W.B.F., 1973. The origin of the Mediterranean evaporites. In: W.B.F. Ryan and K.J. Hsü (Editors), Int. Repts. DSDP,13 (Part 1). U.S. Govt. Printing Office, Washington, D.C, pp. 1203-1231.

Hsü, K.J. and Giovanoli, F., 1979. Messinian event in the Black Sea. Palaeogeogr. Palaeoclimatol. Palaeoecol. 29, 75-93.

Jousé, A.P. and Mukhina, V.V., 1978. Diatom units and the paleogeography of the Black Sea in the late Cenozoïc (DSDP, Leg 42B). In: D.A. Ross and Y.P. Neprochnov (Editors), Int. Repts. DSDP, 42 (part 2). U.S. Govt. Printing Office, Washington, D.C., pp. 903915.

Kojumdgieva, E., 1983. Paleogeographic environment during the desiccation of the Black Sea. Palaeogeogr. Palaeoclimatol. Palaeoecol. 43, 195-204.

Koreneva, E.V. and Kartashova, G.G., 1978. Palynological study of samples from holes 379A, 380A, LEG 42B. In: D.A. Ross and Y.P. Neprochnov (Editors), Int. Repts DSDP, 42 (part 2). U.S. Govt. Printing Office, Washington, D.C., pp. 951-992.

Letouzey, J., Biju-Duval, B., Dorkel, A., Gonnard, R., Kristchev, K., Montadert, L. and Sungurlu, O., 1977. The Black Sea: a marginal basin; geophysical and geological data. In: B. Biju-Duval and L. Montadert (Editors), International Symposium on the Structural History of the Mediterranean Basins. Technip, Paris, pp. 363-376.

Lofi, J., Rabineau, M., Gorini, C., Berné, S., Clauzon, G., De Clarens, P., Dos Reis, A.T., Mountain, G.S., Ryan, W.B.F., Steckler, M. and Fouchet, C., 2003. Plio-Quaternary prograding clinoform wedges of the Western Gulf of Lions continental margin (NW Mediterranean) after the Messinian Salinity Crisis. Mar. Geol. 198, 289-317.

Lofi, J., Gorini, C., Berne, S., Clauzon, G., Tadeu Dos Reis, A., Ryan, W.B.F. and Steckler, M.S., 2005. Erosional processes and paleo-environmental changes in the Western Gulf of Lions (SW France) during the Messinian Salinity Crisis. Mar. Geol. 217(1-2), 1-30.

Marinescu, F., Ghenea, C. and Papaianopol, I., 1981. Stratigraphy of the Neogene and the Pleistocene Boundary, Guide Excursion A6, Guide book ser. 20, 12th Congr. Carpatho-balkan, Inst. Geol. Geopys. Bucarest.

Marunteanu, M., 1992. Distribution of the calcareous nannofossils in the Intra - and Extra Carpathian areas of Romania. Knihovnicka ZPN 14b(2), 247-261. 
Marunteanu, M. and Papaianopol, I., 1998. Mediterranean nannoplankton in the Dacic basin. Rom. J. Stratigr. 78, 115-121.

Meulenkamp, J.E. and Sissingh, W., 2003. Tertiary palaeogeography and tectonostratigraphic evolution of the Northern and Southern Peri-Tethys platforms and the intermediate domains of the African-Eurasian convergent plate boundary zone. Palaeogeogr. Palaeoclimatol. Palaeoecol. 196, 209-228.

Mitchum, R.M. and Vail, P., 1977. Seismic stratigraphic interpretation procedure. In: C.E. Payton (Editor), Seismic stratigraphy - Applications to hydrocarbon exploration. AAPG mem., pp. 135-143.

Montadert, L., Letouzey, J. and Mauffret, A., 1978. Messinian event: seismic evidence. In: K.J. Hsü and L. Montadert (Editors), Int. Repts. DSDP, 42 (part 1). U.S. Govt. Printing Office, Washington, D.C., pp. 1037-1050.

Muratov, M.V., 1951. History of the Black Sea Basin in relation to adjacent areas. Byull., Mosk. Ova Ispyt. prir., Otd. Geol. 24(1), 7-34.

Nikishin, A.M., Korotaev, M.V., Ershov, A.V. and Brunet, M.F., 2003. The Black Sea basin: tectonic history and Neogene-Quaternary rapid subsidence modelling. Sediment. Geol. 156(1-4), 149-168.

Nikolayeva, Y.Y., Pustil-nikov, M.R. and Shlezinger, Y., 1980. Struktura osadochnogo chekhla severo-zapadnoy chasti Chernomorskogo glubokovodnogo basseyna, translated Title: Structure of the sedimentary cover in the northwestern part of the Black Sea abyssal basin. Byulleten' Moskovskogo Obshchestva Ispytateley Prirody, Otdel Geologicheskiy 55(3), 3-16.

Okay, A.I., Sengör, A.M.C. and Görür, N., 1994. Kinematic history of the opening of the Black Sea and its effect on the surrounding regions. Geology 22, 267-270.

Papaianopol, I. and Marinescu, F., 1995. Lithostratigraphy and age of Neogene deposits on the Moesian Plat-form, between Olt and Danube Rivers. Rom. J. Stratigr. 76, 67-70.

Papp, A., Cicha, I., Rögl, F., Senes, J., Steininger, F.F. and Baldi, T., 1974. Principes de la subdivision stratigraphique de la Paratéthys centrale. Mem. BRGM. 78(2), 767-774.

Popescu, S.M., 2001. Végétation, climat et cyclostratigraphie en Paratéthys centrale au Miocène supérieur et au Pliocène inférieur d'après la palynologie, $\mathrm{PhD}$ Thesis, Université Claude Bernard - Lyon 1 (France), 233 pp.

Popescu, S.-M., 2006. Late Miocene and early Pliocene environments in the southwestern Black Sea region from high-resolution palynology of DSDP Site 380A (Leg 42B). Palaeogeogr. Palaeoclimatol. Palaeoecol. 238(1-4), 64-77.

Robinson, A.G., Rudat, J.H., Banks, C.J. and Wiles, R.L.F., 1996. Petroleum geology of the Black Sea. Mar. Petrol. Geol. 13(2), 195-223.

Robinson, A.G., Spadini, G., Cloetingh, S. and Rudat, J.H., 1995. Stratigraphic evolution of the Black sea : inferences from basin modeling. Mar. Petrol. Geol. 12(8), 821-835.

Rögl, F., 1998. Paleogeographic consideration for Mediterranean and Paratethys seaways (Oligocene to Miocene). Ann. Naturhist. Mus. 99(A), 279-310.

Rögl, F., 1999. Mediterranean and Paratethys. Facts and hypotheses of an Oligocene to Miocene paleogeography (short overview). Geol. Carpath. 50(4), 339-349.

Rögl, F. and Steininger, F.F., 1983. Vom Zerfall der Tethys zu Mediterrane und Paratethys. Die neogene Paläogeographie und Palinspastik des zirkum-mediterranean Raumes. Ann. Naturhist. Mus. Wien 85(A), 135-163.

Ross, D.A. and Neprochnov, Y.P., 1978. Int. Repts. DSDP, 42 (part 2). U.S. Govt. Printing Office, Washington, D.C., 1244 pp.

Ryan, W.B.F. and Hsü, K.J., 1973. Int. Repts. DSDP,13 (Part 1 \& 2). U.S. Govt. Printing Office, Washington, D.C, 1447 pp. 
Schrader, H.J., 1978. Quaternary through Neogene history of the Black Sea, deduced from the paleoecology of diatoms, silicoflagellates, ebridians, and chrysomonads. In: D.A. Ross and Y.P. Neprochnov (Editors), Int. Repts. DSDP, 42 (part 2). U.S. Govt. Printing Office, Washington, D.C., pp. 789-902.

Semenenko, V.N. (Editor), 1987. Stratigraphic correlation of the Upper Miocene and Pliocene deposits of the Eastern Paratethys and Tethys. Naukova Dumka, Kiev.

Semenenko, V.N. and Lyul'eva, S.A., 1978. Direct Mio-Pliocene correlations between the Eastern Paratethys and Tethys, Cenozoic stratigraphy of the Northern Black Sea area and the Crimea. Dnepropetr. Gos. Univ., Dnepropetrovsk, pp. 95-105.

Sinclair, H.D., Juranov, S.G., Georgiev, G., Byrne, P. and Mountney, N.P., 1997. The Balkans thrusts wedge and foreland basin of the eastern Bulgaria: Structural and stratigraphic development. In: A.G. Robinson (Editor), Regional and petroleum geology of the Black Sea and surrounding region. AAPG mem., Tulsa, pp. 91-114.

Snel, E., Marunteanu, M., Macalet, R., Meulenkamp, J.E. and van Vugt, N., 2006. Late Miocene to Early Pliocene chronostratigraphic framework for the Dacic Basin, Romania. Palaeogeogr. Palaeoclimatol. Palaeoecol. 238(1-4), 107-124.

Steininger, F.F. and Papp, A., 1979. Current biostratigraphic and radiometric correlations of Late Miocene Central Paratethys stages (Sarmatian s.str., Pannonian s.str., and Pontian) and Mediterranean stages (Tortonian and Messinian) and the Messinian Event in the Paratethys. Newsl. Stratigr. 8(2), 100-110.

Stoffers, P. and Müller, G., 1979. Carbonate rocks in the Black Sea basin : indicators for shallow water and subaerial exposure during Miocene-Pliocene time. Sediment. Geol., 23(1-4), 137-147.

Tambrea, D., Dinu, C. and Sampetrean, E., 2002. Characteristics of the tectonics and lithostratigraphy of the Black Sea shelf, offshore Romania. In: C. Dinu and V. Mocanu (Editors), Geology and tectonics of the Romanian Black Sea shelf and its hydrocarbon potential. B.G.F Special Volume ${ }^{\circ} 2$, pp. 29-42.

Traverse, A., 1978. Palynological analysis of DSDP Leg 42B (1975) cores from the Black Sea. In: D.A. Ross and Y.P. Neprochnov (Editors), Int. Repts. DSDP, 42 (part 2). U.S. Govt. Printing Office, Washington, D.C., pp. 993-1015.

Zonenshain, L.P. and Le Pichon, X., 1986. Deep basins of the Black Sea and Caspian Sea as remnants of Mesozoic back-arc basins. Tectonophysics 123, 181-211.

Zubakov, V.A., 2000. The Pliocene of the Pontic-Caspian region and its correlation. Stratigr. Geol. Correl. 8(1), 60-76. 